\title{
The Great Achievement of Greek-Owned Shipping (1946-2017) and Keynes' Animal Spirits
}

\author{
Alexandros M. Goulielmos 1,2 \\ ${ }^{1}$ Department of Maritime Studies, University of Piraeus, Piraeus, Greece \\ ${ }^{2}$ Shipping Division of Business College of Athens, Athens, Greece \\ Email:am.goulielmos@hotm ail.com
}

How to cite this paper: Goulielmos, A.M (2017) The Great Achievement of GreekOwned Shipping (1946-2017) and Keynes' Animal Spirits. Modern Economy, 8, 11861210.

https://doi.org/10.4236/me.2017.810082

Received: September 14, 2017

Accepted: October 27, 2017

Published: October 30, 2017

Copyright $\odot 2017$ by author and Scientific Research Publishing Inc. This work is licensed under the Creative Commons Attribution International License (CC BY 4.0).

http://creativecommons.org/licenses/by/4.0/

\section{Open Access}

\section{Abstract}

The Greek-owned Shipping's great achievement since 1946, time when $~ 100$ liberties acquired, is presented. It lies in the disproportion between a large global fleet and a small national seaborne trade. We also presented the 1300 years historical link between 21 Greek islands, and at least 31 great ship owners; kinship ties created by living in the same island, and... by marriages among fleet owners; the common participation in the ship capital of the ship

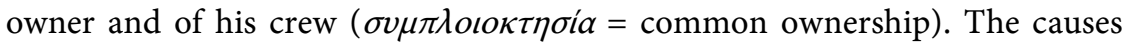
shown were 1) international and 2) national: 1) Greeks were cross-traders; the shipping policy of oil companies favored them; the seaborne trade expansion too. 2) Greek-fatherland was occupied for 376 years (1453 - 1829) by Turks; Greek merchants/ship owners had to work abroad (UK 1800s; NY 1939; Canada 1939); Greeks became skilled in owning and building ships since the time of Themistocles (524 - 459 BC), who saved Europe from Persians. We showed four additional important factors: 1) Tradition, 2) Time, 3) Strategy and 4) Setoff. Tradition found responsible for $49 \%$ (in tonnage terms) of the fleet owned by top ( $\geq 1 \mathrm{~m} \mathrm{dwt}$ ) 74 shipping companies, i.e. $146 \mathrm{~m}$ dwt in 2016 were traditional. This proved that Greeks-at least 1 out of 2-have a "nontraditional" shipping DNA. We found that in May, 2009, there were 47 top Greek-owned shipping companies owning $120.5 \mathrm{~m}$ dwt and by 2016 they were 77, owning $299 \mathrm{~m}$ dwt! Alfred Marshall's Law for decreasing cost industries holds here... Finally, we showed the strategy of Greek-owned shipping, which was: "buy used ships-at rock bottom prices-larger and younger than the ones you are about to sell"; "sell/scrap smaller and older ones". Setoff, as shown, is the innovative element originating in Greek DNA: a subsequent generation frequently forms its own opinion of how the company had to be 
managed... This leads to set off by one or two family-members in creating their own company. The setoff companies, nevertheless, showed faster growth, demolishing-out the old saying: "strength is in unity". These set off companies owned $\sim 110 \mathrm{~m}$ dwt in 2016 .

\section{Keywords}

Shipping Tradition, Renewal Strategy, Set off Practice, Hellenic Shipping Great Achievement since 1946, Cross-Trading, Oil Companies' Policy

\section{Introduction}

The Greek-owned-shipping consists of ships owned by Hellenes independently of their flag. The share of this fleet to world total continued to grow till early 2017, reaching $\sim 20 \%$ in $\mathrm{dwt}^{1}, 4600$ Ships, $341.2 \mathrm{~m}$ dwt and $\sim 50 \%$ share in EU's fleet $^{2}$.

The great achievement-GA lies in the disproportion between the large world Hellenic fleet and the small volume of country's seaborne trade. This accomplished under the following factors-negative and positive: 1) absence of maritime infrastructure at home; 2) slim own capital; 3) erratic "help", or occasional harm, caused by Government; 4) absence of coal, oil and iron-ore; 5) national officers and ratings-possessing long traditional seamanship helped the whole endeavor; 6) the existence of international entrepreneurs with ship-owning tradition/knowhow and skill in owning ships; 7) the use of foreign crews, under favorable terms for ship owners after 1985; and 8) the excellent legal and institutional framework provided at home since 1953.

GA started in 1946-when Greeks bought 106 ships (a total >1 m GRT) from those built for world's Liberty by USA during $2^{\text {nd }}$ World War. In 1947, Hellenic fleet's share was $1.5 \%$ of world. In addition, $70 \%$ of the Greek-flagged fleet destroyed during $2^{\text {nd }}$ World War; we may say that 1946 , is the year of the re-birth of the Hellenic shipping Phoenix.

Academe suggests the building-up of a maritime tradition to nations seeking an exceptional progress in owning ships... This was done by UK. But what happened to UK? Sturmey [1], however, asked: "Why has the tonnage of ships registered in the UK declined from over $45 \%$ of the world total (1900) to about $16 \%$ ?" Four factors he found responsible: changes in economic factors, interference with the competitive process, random factors and the low growth of UK fleet from 1890 to 1960 (=0.6\%). UK owned worldwide $26 \mathrm{~m}$ GRT $(\sim 11 \%)$ in 1970, in $1980 \sim 27 \mathrm{~m}$ GRT ( 6.5\%) and in $200014.6 \mathrm{~m}$ GRT ( 3\%). UK had a sharp fall from $33 \mathrm{~m}$ GRT (1976) to $5 \mathrm{~m}$ (in 1994). By 2015 reached $\sim 50 \mathrm{~m}$ dwt (3.4\%).

\footnotetext{
${ }^{1}$ Greece owned $280 \mathrm{~m}$ dwt (ships > 1000 GT); Japan: 235; Germany 128; USA 60; Norway 50; Denmark 39; Italy $\sim 24$; Belgium $~ 21$; \& Russia $\sim 20=\sim 857$ dwt (UNCTAD 2015).

${ }^{2}$ Veniamis Th., President of “Greek ship owners union" 1917-2017, (Annual Report, 2015-2016).
} 
Similarly, USA in 1970 owned $^{3}: 18.5$ m GRT ( 8\%), in $1990 \sim 21$ m GRT (5\%), in $2000 \sim 32 \mathrm{~m}$ GRT ( $\sim 6 \%)$. The fall of USA fleet was continuous since 1949-from 30 $\mathrm{m}$ GRT to $19 \mathrm{~m}$ GRT in 1994. By 2015, the fleet reached $\sim 60 \mathrm{~m}$ dwt ( 4\%).

A critical year for a negative growth by the top 5 global fleets-including Norway ${ }^{4}$ and Greek-owned fleet-was 1976. In 1975, the shipping spot market suffered a serious recession, and years 1975-1978, were in depression for all sizes of vessels; moreover, 1977 imposed severe liquidity problems on shipping companies [2]. In 1979, the supply of tonnage rose only $2.5 \%$, indicating fleets' growth fall. Moreover, the "Yom Kippur War" (1973) led to a structural depression in the tanker market, till 1988. From 1979 to 1987 the tanker market passed a disaster... Tanker recession lasted 4 years (1992-1995).

Moreover, 10 nations climbed up to top 20 fleets globally by 2015: China ${ }^{5}: 160$ m dwt; Singapore: $\sim 90$ m; Rep. of Korea: $\sim 80$ m; Hong Kong: $\sim 73$ m; Rep. of Taiwan: $\sim 45$; Bermuda: $\sim 41 \mathrm{~m}$; Turkey: $\sim 31 \mathrm{~m}$; Monaco: $\sim 30 \mathrm{~m}$; India: $\sim 25 \mathrm{~m}$; Brazil: $24 \mathrm{~m}$; total $\sim 599 \mathrm{~m} \mathrm{dwt}$.

\section{Paper's Aim}

The paper wished to reveal the causes of the Hellenic Shipping great achievement, using data on 74 top ( $\geq 1 \mathrm{~m} \mathrm{dwt}$ ) Greek-owned shipping companies(Table A1) - in end-2016. Particular attention is paid in set off ${ }^{7}$, i.e. the phenomenon of certain members of a shipping family-company to set off to create their own. For this "animal spirits" should prevail, we believe, as set off is a major decision creating high risk.

\section{Paper's Structure}

Next is a literature review. Then, the role played by internationalization of shipping in Greek one is examined. Next, we presented the growth of Greek-owned shipping since 1949 and till 2016. Then, we examined the role of tradition. Next, we presented the phenomenon of the increasing size of Greek-owned shipping companies over time. Then, the strategies, applied over time by Greek shipping companies for expansion/renewal are presented; finally, we conclude after presenting analytically the set off in 13 case-studies.

\section{Literature Review}

Deakin and Seward [3] showed that ships' technology became more expensive,

\footnotetext{
${ }^{3}$ Theotokas \& Harlaftis [19].

${ }^{4}$ Norway's fleet fell from 1976 to 1988; rose sharply by 1990 and fell again by 1994. In 2015 owned $\sim 48 \mathrm{~m} \mathrm{dwt}$.

${ }^{5}$ Adding up China's fleet, Hong-Kong's and Taiwan's Rep., we get $278 \mathrm{~m}$ dwt...

${ }^{6}$ UNCTAD, 2015, (ships > 1000 GT).

${ }^{7}$ Lloyd's Shipping Economist, (Sept. 2011): “Greek modernization goes on”, p. 5-6; Theotokas \& Harlaftis [19].

${ }^{8}$ Keynesian term indicating that the major investments are usually undertaken by entrepreneurs, despite inherent uncertainties; these have the courage to try seeing out there opportunities...
} 
and ships were more specialized ${ }^{2}$. For Lawrence [4], internationalization was a successful decision for all prominent shipping managers, who secured funds, ships, crews and charters internationally. Svendsen [5] (no date) argued that shipping companies were independent, not multinational. Metaxas and Parker [6] proved that ships grew in average value.

Farthing and Brownrigg [7] argued that GATT promoted trade, and similarly did WOT (1995)—of a broader goal—along with: NAFTA (1992/94), FTAA (2005), Mercosur, ASEAN, and African Union (2002) etc. Moreover, maritime nations increase over time (23\%, 1985-1995, to 172). Recently (2017) globalization and climatic change placed in dispute by USA President. EU, however, acts towards a different direction for more trade-including cooperation with Japan [8] [9].

Chrzanowski [10] identified capital concentration in shipping, in a much greater emphasis from 1950 to 1973 -than what happened before $2^{\text {nd }}$ world war $^{10}$. We did that here for 2009-2016 for Greek-owned fleet.

Sletmo and Holste [11] argued that the course of international shipping passed 4 waves: $\left(1^{\text {st }}\right)$ the discoveries of new countries-before industrialization. Then, the regional sea transport [12] expanded. Moreover, the creation of colonies led to the establishment of sea links with Metropolis. Colonies provided raw materials to metropolitan factories. Before the merchant marine expanded, colonial powers (=UK, Holland, France, Spain, Portugal, Italy and Belgium) developed Navy, as force required to annex colonies.

( $2^{\text {nd }}$ phase): the nations-mentioned above-dominated in seaborne trade, and created and maintained thereafter serious merchant fleets. Dominance over seaborne trade then was equivalent of being the ruler of the then known world: economically and politically. ( $3^{\text {rd }}$ phase): the link of ship's flag to owner's nationality became looser. Flag indicates the nation from which a ship derives her nationality, i.e. that of owner. This original order frequently violated ${ }^{11}$. Notable is that "the place where a vessel belongs" (=flag) is not without impact from a variety of issues. Economically, e.g., Greek shipowners argue that $\sim \$ 800$ per day is the cost of the Greek flag to a vessel ${ }^{12}$.

Flag can be envisioned-in a metaphor-as an international... "hotel" for ships. First, this was realized by Americans, who in 1918 used Liberian flag. Onassis in 1930s registered vessel "Penelope O" in Panama. The way shore

${ }^{9}$ The Greek shipping company Costamare applied scale economies by building a ship $47 \mathrm{~m}$ longer and $3 \mathrm{~m}$ broader with 24,000 additional hp at almost the same speed, carrying 3,080 additional boxes (2006)...

\begin{tabular}{ccccc}
\hline Length/Year of built & Width & Horse power-hp & Speed & Scale (boxes) \\
\hline $157 \mathrm{~m} / 1985$ & $25 \mathrm{~m}$ & 12,000 & 18.0 & 956 \\
$304 \mathrm{~m} / 2000$ & $40 \mathrm{~m}$ & 78,000 & 25.6 & 6420 \\
$351 \mathrm{~m} / 2006$ & $43 \mathrm{~m}$ & 102,000 & 25.5 & 9500 \\
\hline
\end{tabular}

${ }^{10}$ Svendsen A Stromme [5], The concentration of capital in shipping and the optimum size of shipping companies, Inst. for shipping research, NSE, Bergen.

${ }^{11}$ Originally vessel's Captain chose vessel's flag!

${ }^{12}$ Interview given by shipowner Papadakis to journal “Efoplistis” (2006). 
companies choose their location, the same way ships choose their flag... Many nations dreamed to "build"... "hotels" for ships, for obvious benefits (e.g. "Marshall Islands")..., and even groups of nations (EU wished to establish "EUROS" in 1989). A number of "parallel" registries ${ }^{13}$ — since “1981-1987" crisis-established in Europe (1986) and in Norway (1983). Some called the international "hotels" for ships, "flags of convenience"... becoming targets of ITF (International Transport Federation).

( $4^{\text {th }}$ phase): the separation of "owning" ships from "managing" them... Shipowners are for some time now "independent" from ship operations. Operation is provided by the " $3^{\text {rd }}$ party ship management companies" since 1970s [12] [13] [14] [15] for a fee. Owners, thereafter, paid efforts in finding the required funds, choosing particular vessel to be built or purchased, and selecting shore staff; then all, or part, of ship operations are appointed-over to ship management companies... ("Vafias") ${ }^{14,15}$. This, however, is not a lifestyle shipping, as Greeks, par excellence, live... [15]... The idea to outsource ship operations, economically, is based, on "Economies of scope"... a twin sister of "Economies of scale"16.

The shipowner can also have his/her company listed, so that to obtain the funds required, making him/her independent of commercial banks ${ }^{17}$. The difference of a listed from a non-listed shipping company is not without importance, however. One of the objectives of the listed shipping companies is to maximize shareholders' interests, through improved capitalization, when company is finally sold.

Lifestyle ship-owning exists-for us-when owning a ship is understood ipso facto as...managing her too (ownership = management). Moreover, ship-owning is one of the unique professions, we believe, which fits to the character and mental make-up of Greeks. Owner sees ship-owning not as a profession, but as a way to live. Lifestyle ship-owning allows a person to take all relevant decisions personally_(with no board of directors) - to stay small or become great-to create an unbelievable wealth or just the "necessities" - to stay unknown or become famous (and attracting envy) - to work hard...-to create a company, which will be known only by owner's name (e.g. Aristotelis Socrates Onassis).

Success, in lifestyle ship-owning, is personal-the owner has the opportunity

${ }^{13}$ p. 205, EC Shipping Law, $2^{\text {nd }}$ ed., by Vincent Power, LLP 1998.

${ }^{14}$ Shipping companies needed officers, being in short supply up to 2008; moreover, ISM Code (1998; 2002) required crews familiar with the ship before they sign on; also the idea that firms must be "schools" appeared in management; so, the need of establishing nautical schools at main sea labor supply centers for officers and ratings (India; Ukraine; Philippines; and elsewhere) emerged. These schools established mainly by the " $3^{\text {rd }}$ party ship management companies", which had to look -anyway-after thousands of officers and ratings for their own account (=economies of scope). Certain shipping companies established long ago also "crew agencies" in Philippines and elsewhere. ${ }^{15}$ Most clients use them for crew and technical support.

${ }^{16}$ Economies of scale exists when a company's vessel increases in size (by replacement or technically), and the cost per ton of cargo transported falls. Economies of scope indicate the way scale can be increased. "Economies of scope" appeared in 1992?

${ }^{17}$ Most shipowners believe that banks give umbrellas in sunshine, and demand them back in raining'! Banks-after a depression-are reluctant to help shipowners in liquidity problems. Shipowners then resort to stock exchanges, proving that "crises create opportunities". 
to prove to his enemies, opponents, colleagues-who really is...-making other shipowners to admit him/her to their closed club and allow him/her to marry one of their sons/daughters... (e.g. Onassis; Niarchos). All kinds of ambitions, egoism, and all other human passions, can be satisfied by the lifestyle shipowning-where fame stays... even after death.

\section{The Method Followed}

This paper had the underlying ambition to reveal a secret: why Greeks were great in their shipping endeavor? It is the same question that Adam Smith (1723-1790) posed in his inquiry into the nature and causes of the wealth of Nations (1776). Here we have the wealth of nations but from a particular sector: shipping. An indeed small and unimportant nation Greece-apart from its ancient tradition-with no strategic resources and slim seaborne trade and with non-existing own capital etc. how on earth reached and stayed on the $1^{\text {st }}$ global shipping position? This knowledge surely is useful and to other nations like China and India as well Turkey. Our method was through all along a historical analysis at sector's and companies' level using mainly diagrams and tables and a difficult to find data, spending uncountable time in tracing things out concerning a secret industry, with special emphasis on the last 8 years or so and on protagonists only. This historical model-unlike the established ones-did not leave out nearest present, but connected it to the distant past. These modelswith much economic content-are capable of analyzing changes and situations in the real world that every one suspects, and every one speculates about, but none analyzes them providing convincing figures and names and connecting firms with their entrepreneurs ${ }^{18} \ldots$

\section{The Great Achievement of Greek-Owned Shipping, 1949-2016}

A notable characteristic of Greek-owned shipping is its 1300 years historical link with-all in all-21 islands $\mathbf{s}^{19}$ ! The harder the life ${ }^{20}$ in an island, the more people go to sea, and the more people become shipowners ${ }^{21}$ ! This is the original process

\footnotetext{
${ }^{18} \mathrm{We}$ wish to thank Marine information services for the data they provided to us. ${ }^{19}$ Whittaker [21].

${ }^{20} 31$ shipowners came from: Cephalonia 2: Lykiardopoulos; Vergottis; Ithaka 2: Stathatos; Gratsos; Syra 1: Cotzias; Chios 12: Chandris, Michalos, Los, Fafalios, Pittas, Andreadis, Carras, Livanos, Angelicoussis, Frangos, Tsakos, Xylas; Chios controlled 1/2 Greek-owned fleet. Andros owned 1/4 of Greek tonnage; 5 shipowners: Goulandris, Embiricos, Coulouthros, Polemis, Moraitis; Kassos 3: Kulukundis, Mavroleon, Rethymnis; Oinousses 6: Pateras, Lemos, Hadjipateras, Lyras, Pontikos, Samonas; the shipping families were 199 in 1958, 436 in 1975 (+120\%); in 1958 they created 198 shipping firms and 765 in 1975 ( 2 companies per family). In 1975 37\% of ship-owning families came from 4 islands: Aegean, Ionion; Crete and Peloponnese [18]!

${ }^{21}$ The geographical position of an island also played role in creating shipowners... Chios (in medieval times) was important place of trade route to Constantinople. Moreover, the deals of foreign rulers benefited Chios, under Genoa's rule for 262 years (1304-1566); Genoa controlled trade and warehouses for mastic, alum, salt and pitch. In 1764 Chios owned 6 ships (having $6 \times 15$ sailors); in 1875104 ships; in 1889440 ships ( $440 \times 7$ sailors). Shipping is part of island's culture till this day.
} 
by which Greek-owned shipping created. Moreover, kinship ties between people living in the same place multiplied and strengthened. Capital concentration also appeared through marriages among fleet owners... Greeks had sea not only from 3 sides in their country-and all round in their islands-but also in their soul $^{22}$, in their blood... as well in their dreams (Onassis). Notable is Peloponnese, the island of Pelops, (son of Tantalus-King of Lydia), which created important shipowners (from Arcadia; Mani; Sparta; Gortynia; Ilia and Achaia).

Greek-owned shipping between 1949 and 2013 is presented (Figure 1, in GRT) and between 1988 and 2016 (Figure 2, in dwt).

The Greek-owned shipping-since 1949-grew by a double figure from year to year for a decade, till 1958. From 1959 to 1962, it achieved a single figure or even a negative one (1960: -2.09\%). From 1963 to 1972-over another decadegrew by 2 figures (13\% 1963; 1965: 13; 1967: 11). From 1973 to 1977, by one figure, and from 1978 to 1982, growth rates were low $(<2 \%)$ or even negative (1978 -0.7; $1982-1.6 \% ; 1984-0.5 \%)$, due to tanker and dry cargo depressions. In 1986, it had a negative rate $(-3.8 \%)$ and also in $1989(-0.4 \%)$ and in $1997(-0.2 \%)$. However, the extraordinary worldwide boom in 2003-2008 led to a rapid growth (Figure 2). After 2008, the fleet was stagnant for 5 years (2009 till 2013)-due to global meltdown. Between 2014 and 2015 it recovered (to $\sim 341 \mathrm{~m} \mathrm{dwt)}$.

\section{The National \& International Shipping Environment and Its Role in the Great Achievement of Greek-Owned Shipping}

Internationalization is when the nationality of the coefficients of production, of inputs and of services, and of ship's flag, are partly or wholly, different from the nationality of owner [15] [16] [17]. Ships-since the time they appeared on seapreferred places (=flags) resulting to lower total costs, as this is also the case of globalization [8] [9].

The rise of seaborne trade of certain countries-orphans, partly or totally, of national shipping-gave space to cross-traders-like the Hellenes ${ }^{23}$. UNCTAD did not realize that to have cargoes, was a necessary, but not a sufficient condition, for developing nations to own ships (rule "40-40-20" of UNCTAD-of "Plenipotentiaries on a code of conduct ${ }^{24}$ for liner conferences", 1983)...

\footnotetext{
${ }^{22}$ Andros is also a ship-owners' creating island. It started with mulberry, lemon and silk trades. Exports gave push to shipping, and when stopped, Andrians focused on sea transport. After 1774, (year of the "Kuchuk Kainarjae" treaty between Russia and Ottomans), and before 1821, Andrians-and other Greeks-allowed to own ships. Ships built then by 1790. After Greek independence (1830), Andros became a major center of Greek-owned shipping; the nautical centers of "Galaxidi" and "Hydra" faded. Entire families and crews obtained shares in vessels. Moreover, island villages specialized in providing officers. Ship-owning families were very fertile giving birth up to 9 sons-all tentative shipowners! Originally, sons had also the priority over father's business. Mothers were the dominant personalities in Andros as husbands and sons were on board.

${ }^{23}$ Greek-owned fleet is world's largest cross-trading fleet; $98.5 \%$ of trading capacity in 2015 was carrying cargoes between third countries (Annual report, 2015-2016, Greek shipowners Union).

${ }^{24}$ USA did not ratify it; and EU did so reluctantly, and made it conditionally on "Brussels' package" $1979 ; 1986$ [9].
} 


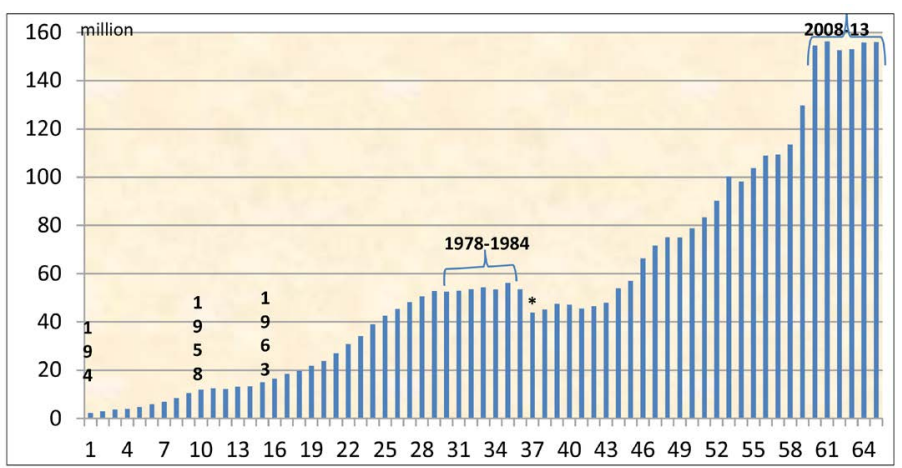

Figure 1. Greek-owned shipping, 1949-2013 (GRT). Source: "Naftica Chronica": 1949-1987; GSCC: 1988-2013; ${ }^{\star} 1985$ (inclusive) ships $\geq$ 1000 GRT.

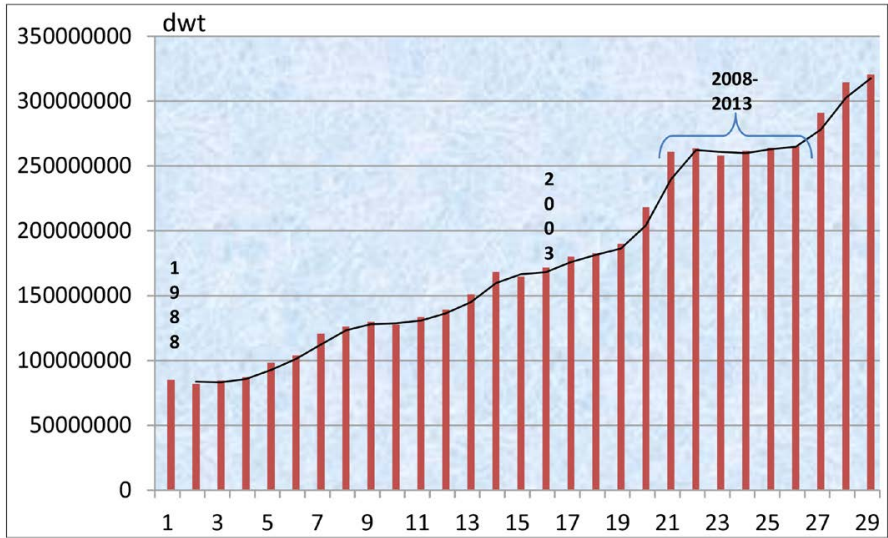

Figure 2. Greek-owned fleet 1988-2016 (dwt) -29 years. Source: Data from GSCC-various years. Trend: 2-year moving average.

Choosing freely a flag for one's vessel is an essential right of the shipowner ${ }^{25}$; but to transport freely other nations' seaborne trade (=cross-trading), is more important, especially for Greeks. This last freedom made Greek-owned shipping independent of the "dwarfish" national seaborne trade. This is the 1 stinternational-cause, which worked for the supremacy of the Greek-owned fleet. This determined also country's external shipping policy all along for centuries till today.

Moreover, Greek fatherland was occupied by Turks for 376 years (1453-1829). Greeks had to abandon their country and became merchants ${ }^{26}$ and shipowners -two in one-using even Turkish ${ }^{27}$ and Russian flags! Greeks - since the time of Themistocles (524 - 459 BC) - became skilled in building ships and this was essential for their future development as shipowners! The above are the $2^{\text {nd }}$ and the $3^{\text {rd }}$ national causes, which helped Greek shipping supremacy (=cross-trading, immigration).

\footnotetext{
${ }^{25}$ Piracy curtailed it. Protectionism also has revived under a new name: "new protectionism". Sometimes bankers or insurers as well as others have a final say in the choice of the flag of a vessel.

${ }^{26}$ Maritime entrepreneurs first were merchants, and, by necessity shipowners, as they had to transport their cargo to the markets.

${ }^{27}$ Turks disliked sea and were mostly mountainous.
} 
Greeks - historically - established before 1830s their shipping offices in London and Cardiff: these were then the centers of "Tramp Shipping"28,29. Greeks were thus near a unique international "trade exchange" (the "Baltic"). Also, Greeks settled where ships could be built at lower prices (UK). Greeks-by necessity - went to New York and Canada in 1939, due to the $2^{\text {nd }}$ world war in Europe. Greeks returned to Piraeus (after 1957) due to a favorable legal framework provided by Greek state since 1953. Greeks when relocated to Piraeus brought gradually commercial banks with them $\left(1960 \mathrm{~s}^{30}\right)$.

Greeks were (are) international, and go (are present) where shipping knowhow, finance, cargoes, and ships-new or $2^{\text {nd }}$ hand-as well freedom of action and opportunities - can be found... Greeks were at places where also their main competitors were, till tele-communications made location less important. Greeks, moreover, used to go where other Greeks worked, like Onassis, who stationed at Dracoulis ${ }^{31}$ office in London gaining there vital information about ships on sale.

The Greek-owned fleet —nationally - had 3 pillars: 1) the shipowner and the crew had a common origin; 2) the owner and the captain-if not the same person - and the officers/ratings formed a "multi-shared ownership"; and 3) almost all shipping people were relatives one with the other.

Shipping should serve global seaborne trade unhindered on a mere (cost) competition. This ideal has been, at times, wounded, and par excellence nowadays, by Piracy. In 2015, like in 2014, 245 maritime piracy incidents occurred costing to the industry more than $\$ 3 b^{32}$.

Essential role for the growth of international shipping played the policy of the 7 oil-companies (=Chevron; Esso; Gulf; Mobil; Texaco; BP and Shell) ${ }^{33}$. These were the main buyers of tanker services. Given that an increase in supply, results in a fall in freight rate... oil companies induced owners to build ships. By so doing increased supply, and at the same time-removed part of the demand from the market ${ }^{34}$ ("with one stone killing two birds"). The above policy made

\footnotetext{
${ }^{28 *}$ Tramp shipping' consists of ships steaming around seeking cargo in various ports-a kind of "ocean taxis". This type of shipping fitted to the character of Greeks and their economic background.

${ }^{29}$ Greek people left for England after 1810 -and mainly after 1820-being merchants. In 1839 in UK were 21 registered companies belonging to merchants and shipowners from Greece. In 1886, about 7\% of the members of "Baltic Exchange" were Greeks. Greeks from 5 islands (Andros, Oinousses, Kassos, Cephalonia and Ithaca) appeared in UK between 1875 and 1900. The Greek shipping offices in UK were: 13 in 1914; 17 in 1938; 105 in 1958 and 177 in 1975; www.naftikachronika.gr Feb. 2016. ${ }^{30}$ One USA bank scrutinized the finance and marine mortgage framework provided by law 2687/1953, before establishing a branch in Piraeus (1960s). Interested-in were also Japanese shipyards and banks, whose Greeks were their best customers.

${ }^{31} \mathrm{~A}$ relative of Costas Gratsos.

${ }^{32}$ UGS, annual report, 2015-6.

${ }^{33}$ Robert M Grant \& Renato Cibin, (1966), Strategy, structure and market turbulence: the international oil majors, 1970-1991, Scandinavian Journal of management, Vol. 12, 2, 165-188. Tusiani M D, (1996), The petroleum shipping industry: a non-technical overview, Vol. 1, Penwell, Tulsa.

${ }^{34}$ Oil companies built their own fleet-before 1973 -to transport about $1 / 3$ of their urgent needs (not without meaning this \%... for a "duopoly game"; Goulielmos et al. [22]). This made oil companies relatively independent of the risk not to find ships in a boom, or pay astronomical sums for, as this has happened.
} 
certain Greek shipowners-like Onassis-protagonists in transporting oil. Five Greek shipping companies were justifiably nominated as "Golden" in the 1950s: "Kulukundis Bros"; "Stavros Livanos"; "Petros Goulandris' sons"; "Onassis" and "Niarchos".

The above "win-win" policy of oil companies composed of: cargo; this was for charter for the entire life of a newly-built ship (15 - 20 years); building finance; this could be secured on long term time charter from a $1^{\text {st }}$ class charterer, as these were the oil companies; profits-due to economies of scale-attained (e.g. Onassis A); world's shipbuilders welcome Greeks, or even decorated them (e.g. Japan decorated C.M. Lemos in 1965)...; on the other hand, oil companies secured sea transport at lower cost; - say for up to $60 \%$ of their needs; oil companies resorted to (volatile) spot market for only a tiny $\sim 7 \%{ }^{35}$ of their needs...

The above practice of oil companies continued till they realized that transporting crude oil is not without a great, and mostly needless ${ }^{36}$, risk; i.e. risk from polluting sea by oil, and the resulting loss of company's prestige, as well paying high compensations of billions of dollars that such event could cause (e.g. "Exxon Valdez"; "Torrey Canyon" etc.). Eventually, "oil traders" and "state oil companies" took over much of the global oil transport ${ }^{37}$ ("Intertanko", 1999) after end-1973.

\section{The Role of Shipping Tradition}

Academe argues that "shipping tradition" is the essential prerequisite for a nation to become great in owning ships... Indeed, ship-owning know-how, in such nations, is handed-down from generation to generation. Greek shipowners-fathers tried, and try, so that their children - no matter, nowadays, their sex-to study ${ }^{38}$ shipping business management, and/or learn it in site, to take-over Company's management after their death.

Also, most shipowners-fathers undertook to teach their children, having them also under close supervision. There are also cases where husbands of ship-owners' daughters are admitted in company's management by "virtue of their marriage". Moreover, Greek shipowners seek to make marriages with other fleet-owners, since ship-owning appeared on sea. At the same time prevent marriages of their daughters with "gold-hunters"...

Harlaftis ([18] 2007 with Theotokas [19]) wrote that a "traditional" shipowner is the one who after $2^{\text {nd }}$ world war (1945) belonged to a $2^{\text {nd }}$ generation (at least). Most of these settled in UK-the "UK based" and in NY. A "traditional" owner of a shipping company over many generations, for us, (= "long tradition") -i.e.

\footnotetext{
${ }^{35}$ Surely the $\%$ mentioned changed from year to year and the $1 / 3$ own fleet of oil companies was lower after end-1973.

${ }^{36}$ After all, oil companies were not sea transport companies, and they had no reason to devote scarce funds for a very risky transport department.

37 “Intertanko", (1999): "Structural changes in the tanker industry", discussion paper, Market research group.

${ }^{38}$ Recent generations stress their previous university and/or postgraduate studies. We believe, younger shipowners need knowledge about "money" and "stock exchanges", which their fathers lacked...
} 
going beyond 1919-is the one, who has established a family-or personalmerchant and shipping company in circa 1830s or even before and passed shipping knowhow-fleet-and company-after his death-over to next generation; the $2^{\text {nd }}$ generation did the same to 3 rd, and so on, till the present day.

The "non-traditional" shipowners are "new shipowners", who entered shipping - after $2^{\text {nd }}$ world war (1945) - coming from other professions - and most of them settled in Piraeus - the "Piraeus-based". The process, by which shipping companies created from 1945 to 2000, shows that more than half (55\% out of 144 companies) were established by: ex-merchant marine officers 39\%; senior shipping office staff, 28\%; and merchants, industrialists and other professionals, $33 \%$ [19].

Tradition is important, however, not only for the important "passing over" of shipping management know-how, and fleet, but also because it means to follow today's strategies, tactics and methods by copying the previous generations ${ }^{39}$ over the same issues... Moreover, learning is gained from tradition, and leads to cost-leadership.

There are also cases where a generation breaks from tradition, especially when shipowners do not marry ship-owners! Notable is that between 1945 and 2000, 45\% out of 144 companies were traditional [19]. We found out also that the $49 \%$ - in tonnage terms - of the top ( $\geq 1 \mathrm{~m} \mathrm{dwt}$ ) 74 companies - in end2016 - was traditional. The traditional companies held $\sim 146 \mathrm{~m} \mathrm{dwt}$ from $\sim 299$ $\mathrm{m}$. So, tradition is responsible for half of the whole Greek-owned shipping between 2009 and 2016.

Moreover, 4 family-companies (5\%) extended beyond 5 generations; 11 (15\%) over 4 generations; 16 (22\%) over 3 generations; 17 (23\%) over 2 generations and 26 (35\%) over 1 generation. So, the majority (65\%) of top shipping companies are there at least for 2 generations and maximum up to 5. Long tradition thus characterizes Greek-owned shipping by a majority rule (75\%).

Worth noting, however, from another point of view, is the fact that $35 \%$ of companies are new (one generation), and most of them are in top positions (positions: 4 - 7, 11 - 12, 15 - 16 as shown in Table A1). This confirms that shipping is in the $\mathrm{DNA}^{40}$ of Greeks and the lack of tradition does not prevent half of Greeks from establishing a shipping company one day given the right opportunities and finance!

\section{The Increasing Size of Shipping Companies}

As time elapses, not only the size (total dwt) of each shipping company increases, but also the number of top, (owning $\geq 1 \mathrm{~m} \mathrm{dwt}$ ), companies becomes higher

\footnotetext{
${ }^{39} \mathrm{We}$ saw companies to have all along steady trends towards only new-buildings or towards only $2^{\text {nd }}$ hand ships from generation to generation.

40“"The character of the Greek shipowners in their business": Fairplay Int. Sh. Weekly, 15/05/1980. Chlomoudis C., (1991), The Greek Merchant Shipping (1910-1993): a coexistence of different production ways, in Greek, unpublished Ph.D. thesis, University of Macedonia.
} 
(Marshall $^{41}$, 1920, in another context). Moreover, in May 2009, the number of ships owned by top Greek-owned companies was 1444 and by end-2016, 2902 (201\%)! Historically, in 1938, no Greek-owned shipping company owned $\geq 1 \mathrm{~m}$ dwt; in 1958, only Niarchos; in 1975: 7 companies; in 1981: 8; in 1990: 6; in 2000: 10; in 2009: 49 companies and in $201677 \ldots$ This proves the "capital concentration" among individual shipping companies in the most clear way.

Figure 3, shows 47 companies owning $\geq 1 \mathrm{~m}$ dwt, which existed in May 2009; among them only 5 companies owned fleets of $\geq 4 \mathrm{~m}$ dwt.

Figure 4 shows 77 companies owning $\geq 1 \mathrm{~m}$ dwt each in 2016. The number of top companies is $67 \%$ higher than that of 2009 ; the number of companies owning over $4 \mathrm{~m}$ dwt were 20 now (owning $180 \mathrm{~m} \mathrm{dwt}$ ) against 5 in 2009 (owning then $29.4 \mathrm{~m} \mathrm{dwt}$ )!

As shown, 18 companies in 2016 owned more than $5 \mathrm{~m}$ dwt each, against 4 in May $2009^{42}$. The top 46 Greek-owned shipping companies (May 2009) owned $120.54 \mathrm{~m}$ dwt (2.62 $\mathrm{m}$ on average). In 2016, the 74 top companies owned 298.64 $\mathrm{m}$ dwt (4.04 $\mathrm{m}$ on average, 1.5 times larger). The top one owned $8.33 \mathrm{~m} \mathrm{dwt}$ (May 2009) and in end-2016 $22.3 \mathrm{~m} \mathrm{dwt} \mathrm{(+267.7 \% ).} \mathrm{In} \mathrm{end-2016,} \mathrm{the} \mathrm{average}$ size per company was $\sim 4 \mathrm{~m}$ dwt, owning $\sim 39$ ships.

\section{Greek-Owned Shipping: Strategies (2016)}

Strategy is a set of planned actions for achieving company's vision. Greek-owned shipping companies adopted different strategies during a boom or during a depression or between them (Figure 5). The dominant strategy was, however, to create a competitive advantage through cutting down the total cost of ships (variable and/or fixed). This policy is known in literature as cost-leadership, belonging to generic strategies.

The generic strategies (term due to Porter ${ }^{43}$ ) are 3: cost-leadership, service differentiation and service focus. The $1^{\text {st }}$ seeks to achieve a cost advantage-over rival firms - by e.g. offering services at lower cost. Shipping then for this must find unexploited opportunities for scale, scope, and learning economies. Tradition provides learning, we believe, as mentioned. The $2^{\text {nd }}$ is not applicable in shipping, while the $3^{\text {rd }}$ is possible, e.g. specialization in gas carriers, LPGs, or $\mathrm{LNGs}^{44}$.

The strategy to grow by buying used tonnage during a shipping depression can reduce fixed cost. This is so as a "rock bottom" price reduces ship's fixed ${ }^{45}$

\footnotetext{
${ }^{41}$ Marshall (1920) argued that the "decreasing cost" industries have $\infty$ elasticity of supply over long periods. So there are no limits to growth in the size of firms - something incompatible with competition... In shipping, however size is compatible with (pure) competition, because each charterer cannot influence total seaborne trade (=demand). In contrast, Supply can be influenced if a shipping company orders a few million dwt, as this happened in 1985 (the Sanko case).

${ }^{42}$ Not all 46 companies increased their tonnage between mid-2009 and end-2016, but only 5 companies reduced their 2009 tonnage by 2016: Allocean/Paragon (Boduroglu); European Nav. (Karnessis); Carras (Hellas) SA; Polyar (P Hadjiioannou) and Kristen (Angelicoussis).

${ }^{43}$ Porter M, (1980), “Competitive strategy”, Free Press, NY.

${ }^{44}$ Besanko et al. [20].

${ }^{45}$ This cost in a newbuilding covers $1 / 2$ of total cost!
} 


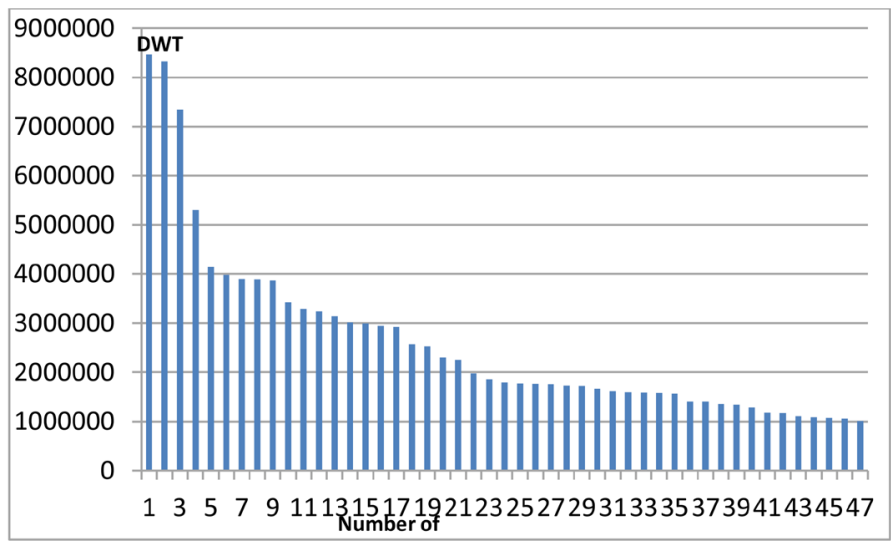

Figure 3. The tonnage owned by the top ( $\geq 1 \mathrm{~m} \mathrm{dwt}) 47$ shipping companies (May 2009). Source: Data: "Marine Information Services".

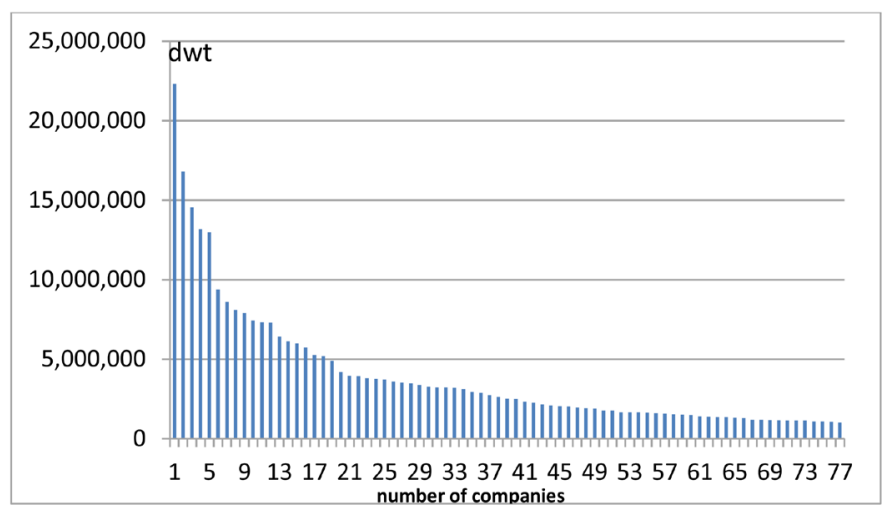

Figure 4. Companies owning $\geq 1 \mathrm{~m}$ dwt in end-2016. Source: Data: Marine information services.

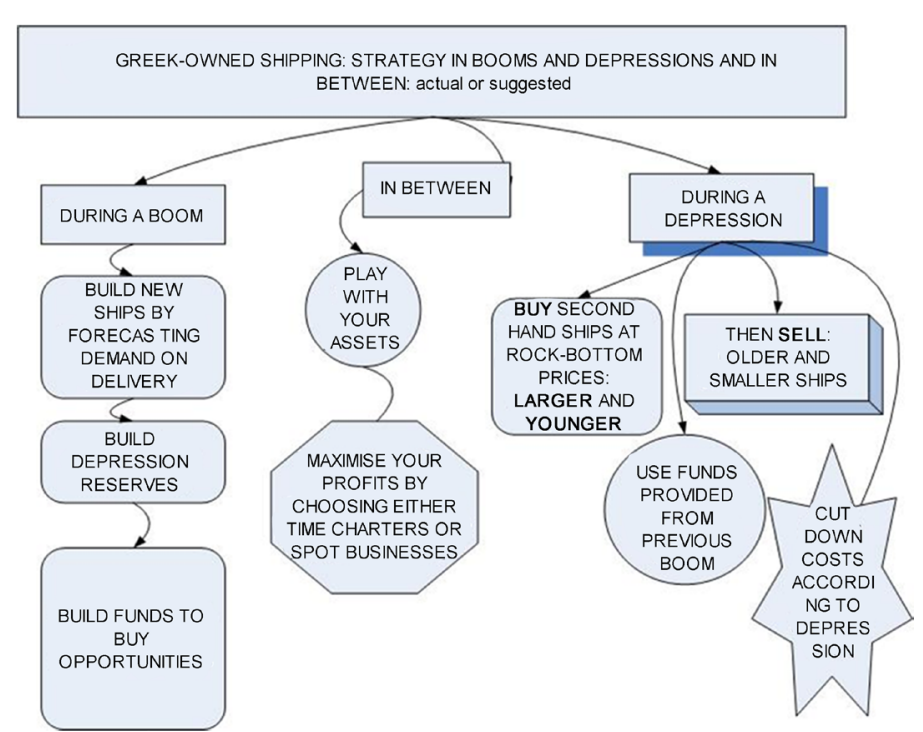

Figure 5. Greek-owned shipping strategy.

(capital) cost drastically, coupled with a larger size-economies of scale-and a younger ship-economies of age - than the one smaller and older sold/scrapped 
thereafter (Table 1). Reduction of total cost leads ${ }^{46}$ also to a competitive advantage.

As a result of the above strategies, total fleet either remains stagnant or falls slightly or even increases, because renewal process is carried-out with larger ships. This explains why Greek-owned fleet-during depressions-did not fall, while depressions affect more or less all ${ }^{47}$ shipowners.

During booms, the new-building ${ }^{48}$ programs may follow economies of scale; so fleet's growth is faster ${ }^{49}$ from year to year. This policy brings also an average cost reduction, which provides also a competitive advantage, as well as economies of age, which is important for charterers, and the conformity with latest environmental regulations. New-building programs must be followed, however, by an accurate forecasting of their freight market at the time of delivery... as certain Greek shipowners learned that in the hardest way.

Given that liquidity is a serious factor during a shipping crisis, the years within the boom (2003-2008), are extremely helpful in fleet's subsequent renewal and expansion for the funds they can provide. The reserves built-up during a boom (2003-2008) are proved to be gold during next depression (2009-2017). It goes without saying that exploiting opportunities is not possible without own cash.

In Table 1, we present the purchasing activity of the top 10 maritime nations.

As shown, Greece paid $\$ 3.750 \mathrm{~b}$ to buy 285 used ships. Greeks paid $\$ 13.16 \mathrm{~m}$ for an average price for the ships they bought, and received $\$ 11.84 \mathrm{~m}$ for the ships they sold. This $\$ 1,320,000$ difference per ship was due to either larger size and/or smaller age. Greeks by this strategy killed three birds with one stone: bought cheaper (rock bottom) $)^{50}$, larger, younger ships; sold/scrapped older, smaller ones; using funds from the preceding boom"...

As far as the asset-playing is concerned (Figure 5), this has also to follow best timing, as all other shipping decisions. It is true that a well-timed sale surpasses 3 yearly profits (from operations). Companies should play with the assets, maximizing profits from all opportunities. The difficult decision, however, is not asset playing, but to know in advance whether time charter or spot will provide the greater profit... Shipowners turned to spot market with all their heart during 2003 to 2008 due to exceptional profits there... but later.

\footnotetext{
${ }^{46} \mathrm{We}$ have to compare the cost of a newbuilding and the cost of a similar (type, size and technology) 5 -years of age used one, owned by Greeks, offering similar services, to understand this strategy.

${ }^{47}$ In 1981-1987 serious crisis Greeks had not as much tonnage in tankers as they had in dry cargoes. The crisis in dry cargoes came with a delay of 2 years (1983) providing time to react. Greeks, as the statistics demonstrate (not shown here), keep today a balance between dry ships and liquid ones. They do not put all eggs in one basket.

${ }^{48}$ For new-buildings Greeks paid $\$ 1.90 \mathrm{~b}$ for $\sim 90$ ships ( $\$ 21 \mathrm{~m}$ on average).

${ }^{49}$ Onassis realized that fast tonnage growth could not be achieved by using past profits and by buying one used ship at a time (usually small-sized). Fast growth is achieved by using other people's money and by building larger ships - as much as technically possible - in a series of many sister ships. Colocotronis' failure was an example, confirming, however, the anti-Onassis attitude. Onassis was a win-win mind, but most circumstances favored him, unlike Niarchos.

${ }^{50}$ Our stress is on "rock bottom", as there are many examples where shipowners bought a vessel believing it to be an opportunity...In the 2nd hand ship market there are "singing many Sirens"... Notable that the price index of used ships fell from 500 units (end-2007) to 50 (end-2016) (!) $(2000=100)($ Clarkson's research).
} 
Table 1. Top 10 shipping powers-plus world, and their purchasing activity, 2016.

\begin{tabular}{cccc}
\hline & $\begin{array}{c}\text { Purchases 2016 } \\
\text { (billion \$) }\end{array}$ & Number of ships & $\begin{array}{c}\text { Average price } \\
\text { (million \$) }\end{array}$ \\
\hline $\begin{array}{c}\text { World total } \\
\text { Nations, which paid }>\end{array}$ & 15.44 & 1244 & 12.41 \\
price than World average: & $3.750 ; 24.3 \%$ & $285(23 \%)$ & 13.16 \\
Greece & 0.293 & 21 & 13.95 \\
Russia & 0.413 & 29 & 14.24 \\
Denmark & 0.447 & 23 & 19.43 \\
India & 0.719 & 36 & 19.97 \\
Singapore & 1.200 & 45 & 26.67 \\
Norway & & & \\
Nations, which paid $<$ & & 34 & 6.18 \\
World average price: & 0.210 & 24 & 6.50 \\
Turkey & 0.156 & $155(12.5 \%)$ & 9.03 \\
Far East & 1.400 & 29 & 12.07 \\
China & 0.350 & $563(45 \%)$ & 11.54 \\
Germany & 6.500 & &
\end{tabular}

Source: Allied Shipbroking, S \& P report, 03/01/2017.

Finally, the cost reduction during a crisis is an old recipe followed by almost all Greeks.

\section{The Contribution of the Set off Companies}

When the $1^{\text {st }}$ generation in a family-company is followed by the $2^{\text {nd }}$, one should expect some members to form different opinion about how the whole pre-existing scheme had to be... However, "set off" explains the rapid growth of Greekowned shipping better, because the 13 - 14 set off companies presented (out of 74) as a case-study, in the last 7 years $(2009-2016) \ldots$ contributed to the fleet $\sim 110 \mathrm{~m}$ dwt in 2016. Notable is also that the growth by the set off companies is an opposite action to "concentration" through marriages among fleet-owners ${ }^{11}$, which traditionally appeared.

George Procopiou - a shipowner-argued ${ }^{52}$ that in Greek shipping families, often, a generation gap opens, and a lack of communication is created. Moreover, it is in the Greek DNA to disagree one with other, even with one's father. This leads family members to set off after father's death. Moreover, shipping is a fertile ground in creating a different opinion, as there are many crucial issues to decide upon. More important is Procopiou's opinion that each separate compa-

\footnotetext{
${ }^{51}$ A practice not abandoned; lately (2014) Nic. Martinos married G. Procopiou's daughter Helen. Onassis and Niarchos married the daughters of St. Livanos. Exceptions are: Athina Onassis, Philippos Niarchos and Odysseus Laskaridis, who did not marry shipowners.

${ }^{52}$ Interview to journal “ARGO”, 2003.
} 
ny progresses much faster than the old one; and this is the point we wish to stress through 13 selected case studies.

Set-off companies case-studies: 1) Aggelopoulos family: Leader: Theodoros (1875-1953), (from Peloponnese), a shipowner (since 1961) due to company's vertical integration $^{53}$ (i.e. steel industry: 1948). His 4 sons (Aggelos 1904-1995; Dimitris 1907-1986; Panayiotis 1909-2001 and John 1911-1974) established "Evron (Hellas) Agencies". They set off (1998): Theodore established "Metrostar" (which sold out; and came back in 2003); they also established "Arcadia" and "Metrobulk" (2002: run by Konstantinos). "Aegean bulk" took over dry cargoes, in which Panayiotis and George, and sons of Konstantinos, participated. "Arcadia" owned 3.12m dwt and “Aegean" 382,000 dwt in 2016 (total = 3.50 m dwt).

2) Angeliccoussis family: Family leader: Antonis (1918-1989) -radio officer/ Agent-and shipowner (1950). Antonis set off (1968) establishing "Agelef (Lon.)" with D. Efthymiou. He set off again (1971) establishing “Anangel Sh. Enterpr. S A", with Pateras G $\mathrm{M}^{54}$. Anna set off (in 2000). John re-bought "Anangel American". "Kristen" managed the tankers for both. Anna married Chr. Kanellakis, owner of "Alpha Tankers \& Freighters". “Anangel” owned $3.24 \mathrm{~m}$ dwt (2009); $14.34 \mathrm{~m}$ (2010); $19.3 \mathrm{~m}$ (2015) and $22.3 \mathrm{~m}$ (2016)! Anna owned $8.10 \mathrm{~m}$ dwt (2016), including Kanellakis' fleet, 2.52m dwt (2009). Both: 30.4m dwt...

3) Comninos C family: the Shipowner was Constantinos (1939-) (since 1965); with his brother Antonis (1946-) est. “Comninos Bros Sh. Co.” (1972). They set off est. "International Reefer Services" and "Target Marine” (Antonis) (end-1980s). Antonis owned $1.04 \mathrm{~m}$ dwt in 2015 and $1.67 \mathrm{~m}$ dwt in 2016.

4) Coustas Family: Leader: Dimitris (1928-) (from Peloponnese), establishing “Roumeli Sh. Co" (1963) with N Grigoriou; renamed “Danaos” (1975). Dimitris set off (1970). His son John (1956-) joined company (1986) and took over (1987). In 2009 it owned $1.97 \mathrm{~m} \mathrm{dwt;} 2.21 \mathrm{~m}$ in 2010; 4.12 in 2010 and $3.97 \mathrm{in}$ 2016.

5) Empiricos family: Epaminondas (1943-) set off in 1969-a grandson of Epam. K. (1858-1924), whose 3 sons established "S G Embiricos" in Cardiff (1896), managed ${ }^{55}$ by George (1906-1967), Nikolaos (1910-1941) and Irini Zafiropoulos (1900-1982). Epam. established "Buenamar" Co Naviera" (Piraeus) with Philippos Alex. (1943-). “Aeolos”, however, owned in 2009 1.72m dwt; in 2010 1.92; in $20153.56 \mathrm{~m}$ and in $20163.72 \mathrm{~m}$ (+216\% since 2009).

6) Fragkos N J family: Leader: Nikolaos (1926-), captain and shipowner (1960). He cooperated with N Moundreas establishing “Good Faith" (1964). He had 3 children: John (who established "Seaways" since 1990s; owned 336,337 dwt in 2016); Aggeliki (establishing "Franser") and Maria Pappis. Most important is Aggeliki, established 4 companies starting with the name "Navios" (2004). In 2009 owned $1.58 \mathrm{~m}$ dwt; in $20103.16 \mathrm{~m}$; in $201514.24 \mathrm{~m}$ and $14.55 \mathrm{~m}$ dwt in 2016 !

\footnotetext{
${ }^{53}$ Vertical integration applied by: "Prodromos Lines", Niarchos, Vardinoyiannis, Latsis etc.

${ }^{54}$ Pateras set off in 1985, establishing "Common Progress S A", owning 342,158 dwt (2016).

${ }^{55}$ Sons and daughters of Stamatis G. Empiricos.

${ }^{56}$ It did not appear in top ( $\left.\geq 228,771 \mathrm{dwt}\right) 200$ shipping companies in 2016.
} 
7) Golden Union families: Company is made-up by 3 families: leaders: Evang. Andreadis, El. Veniamis and Alex. Gavriil. The $1^{\text {st }}$ was captain-married Kalliopi, daughter of Pan. Laimos, obtaining 2 children: Marianthi and Christoforos. The $2^{\text {nd }}$ was captain and shipowner with partners; "Diana Shipping Agencies" established (1972) by Veniamis, Simos Palios and Is. Sarantis. Veniamis set off in 1976. He obtained 2 sons: Theodore and Michalis. The $3^{\text {rd }}$-married Desp. Lyrasowned one liberty (1946) in cooperation with Andr. Vergotis. He obtained 3 children, but only Zoi and George survived. The Golden Union founded in 1977 by Veniamis Th., G Gavriil, Mar. and Christoforos Andreadis and Is. Sarantis, who set off in 1980 .

8) Goulandris family: Leader ${ }^{57}$ : John (1840-1928)—steamship owner. Nikolaos set off in 1952 establishing "N J Goulandris". His 3 sons ${ }^{58}$ John (1923-), Leonidas and Alexandros (1927-) established “Andriaki" (1953). “Andriaki” owned 896,701 dwt in 2009; $1.61 \mathrm{~m}$ in 2010; $2.02 \mathrm{~m}$ in 2015-16! Basil took over "Goulandris Bros" (1952), with his sons John and Konstantinos, who took over "Goulandris Bros Hellas" (Piraeus) joined by his grandsons. In end 2016 it owned 409,445 dwt. Petros, married Chryssis Dampasis, and had 5 sons: John (1907-1950); George (1908-1974); Basil (1913-1994); Nikolaos (1913-1983) and Konstantinos (1916-1978), who set off, and established "United ${ }^{59}$ Sh. \& Trad." (1947) (Piraeus), run by Basil during 1980s, together with his nephews and his grandsons (3, all with the name Petros $\left.{ }^{60}\right)$. The 2 last "set off companies" owned $2.43 \mathrm{~m} \mathrm{dwt}$ in 2016.

9) "Igglessis family": The $4^{\text {th }}$ generation set off (in 1985). "Andrianopoulos family" set off and then Igglesis'. Three cousins ${ }^{61}$ set off establishing "Samos Steamship" (1991). In management involved are Nikos, Antonis and John. "Samos" in 2010 owned $1.78 \mathrm{~m} \mathrm{dwt} ; 2.01$ in 2015 and $2.50 \mathrm{~m}$ in 2016.

10) Kollakis L. family: Michalis- $3^{\text {rd }}$ generation-set off in 1974 and established "Kappa ${ }^{62}$ Maritime".

11) Lemos/ Laimos family: obtained a steam ship with Pateras \& Hadjipateras (1905). $1^{\text {st }}$ was: Captain Christos (1847-1940), a shipowner (1927); his 3 sons (George, 1900-1975; Michail 1905-1973 and Leon/Pantelis (1913-1989), established "Lemos \& Pateras (Lon.)" (1937) \& "Efploia" (1952). Leon set off-using "Efploia" - and establishing "L. Chr. Lemos Ltd" (Lon.) (1972). Leon's children (Christos, 1949-; Marigo ${ }^{63}$, 1948-; Joan, 1952-; and George, 1954) took over in 1989. George set off establishing "Geomar" Co (1996). "Efploia” passed over (2000) to Leon's wife, Aspasia, his daughter Joan (married to Samonas D), his grandsons John (1974-) and Leon Samonas (1975-) ${ }^{64}$. In 2004, Leon Patitsas-

${ }^{57}$ We have counted 15 sons!

${ }^{58}$ They owned also Syros shipyards (since 1970).

${ }^{59}$ Not in the 200 top ( $\left.\geq 233,729\right)$ shipping companies in 2016. Companies established in Piraeus are preferably mentioned. The Goulandris established also “Orion” in 1946 (Lon.).

${ }^{60}$ One son of Maria Laimos; one son of Dolly Cumantaros and the son of George Goulandris.

${ }^{61}$ Stamatis, Nikos and Antonis.

${ }^{62}$ Not in top 200 companies in 2016.

${ }^{63}$ Married to Spyros Patitsas.

${ }^{64}$ None of the above companies were among top 200 in 2016. 
Lemos-a successor-established "Atlas Maritime", which owned $1.15 \mathrm{~m}$ dwt in 2016. Diamantis' family and the sons of Christos set off (in 1951). They established "Avra Sh. Agencies" and participated in the "Oinoussian Maritime". Nikolaos S Laimos set off from "Laimos \& Pateras" and established "N S Lemos \& Co Ltd" (1983). "Avra" renamed "Enesel SA" (2003). "Enesel S A" was in the top 36 companies in 2016 with $2.89 \mathrm{~m}$ dwt. Both set off companies owned $4.04 \mathrm{~m}$ dwt.

12) Martinos John family: the 2 sons set off. Family's leader was (mother) Athina, who est. "Thenamaris" in 1971, a shipowner since 1965. She has 3 sons; Thanassis (1950-), Constantinos (1952-) and Andreas (1954-) (and Helen). Thanassis set off (1991) est. "Eastern". Andreas set off (1997) est. "Minerva". Eastern owned $3.01 \mathrm{~m} \mathrm{dwt}, 3.70,3.46$, and 3.59 (2009-2016) and Minerva $3.29 \mathrm{~m}$, $4.49,6.85$, and $7.32 \mathrm{~m}$ dwt or $10.91 \mathrm{~m}$ both in 2016 .

13) Polemis Sp. Mic. Family (1870-1951): his son Leonidas (1909-1971) and his sons Spyros (1944-) and Adamantios (1949-) set off and founded "Polembros Mar." (early 1970s) in Piraeus'. Adamantios set off in 2015 founding "New shipping". "Polembros" owned $3.01 \mathrm{~m}$ dwt (2009), $3.70 \mathrm{~m}$ (2010), 3.46 (2015) and $3.59 \mathrm{~m}$ (2016). "New shipping" owned $5.68 \mathrm{~m}$ (2015) and $6.13 \mathrm{~m} \mathrm{dwt} \mathrm{(2016).} \mathrm{The}$ two companies owned: $9.72 \mathrm{~m} \mathrm{dwt}$.

14) Procopiou family: Procopiou brothers, George and Dimitris, established “Sea Traders SA” (1975), run now by Anna, George’s daughter. Dimitris set off (1996) establishing "Centrofin Management/Marine Trust”, which owned $1.01 \mathrm{~m}$ dwt (2009); $2.65 \mathrm{~m}$ (2010); 3.62 (2015) and $3.94 \mathrm{~m}$ (2016). George founded "Dynacom tankers management" etc., which owned $5.31 \mathrm{~m} \mathrm{dwt} \mathrm{(2009);} 6.62 \mathrm{~m}$ (2010); $12.81 \mathrm{~m} \mathrm{(2015)}$ and $13.18 \mathrm{~m}$ (2016). Total $17.12 \mathrm{~m} \mathrm{dwt.}$

From the above analysis we derived that the above 14 set off companies owned $\sim 110 \mathrm{~m} \mathrm{dwt}$ in end 2016 or $\sim 37 \%$ in tonnage terms among the 74 top companies.

\section{Conclusions}

Greek-owned shipping became great because: Country's attempted occupation by Persians, in $480 \mathrm{BC}$, led General Themistocles to build ships for the first time, and Greeks to become skilled in operating them; Country's occupation by Turks for 376 continues years (1453-1829), forbidding Greeks to build ships till 1774, forced Greeks to become merchants and shipowners by going abroad (UK 1800s); world's acute needs for transport services covered by cross-trading nations (including Greece), after 1945; and (4) the policy of oil companies in boosting the tanker fleets of independent Greek owners, mainly up to 1973.

Capital concentration is manifested by the continuous growth of almost all top ( $\geq 1 \mathrm{~m} \mathrm{dwt}$ ) individual shipping companies owned by Greeks from year to year, between 2009 and 2016. Greek-owned shipping companies in their majority found to increase in size - total tonnage - in very high rates, confirming Marshall's law of decreasing cost industries, and at the same time preserving competition... 46 top shipping companies (May 2009) owned $120 \mathrm{~m} \mathrm{dwt;} \mathrm{and} \mathrm{by} \mathrm{end}$ 
2016, 74 top ones owned $299 \mathrm{~m} \mathrm{dwt}$ ! Capital concentration was a conscious policy of Greek-owned shipping implemented mainly by uniting the fleets through marriages among owners.

Greeks (e.g. Onassis) realized that large fleets are made by using other's people money and by building larger ships in a series of sister ones, than by buying-one at a time-small $2^{\text {nd }}$ hand ship, after saving last year's profits. Greeks realized also that Greek Agriculture was inefficient, and that their fatherland lacked coal, oil or iron ore; 21 rockier and poorer islands-through a number of historical coincidences-created a number of at least 31 important shipowners active till this day. In such nations as Greece, for one to become a merchant was obvious; but one then had to become a shipowner to bring his merchandise to markets. This is the way Greek-owned shipping knowhow maintained and created.

Born in an island meant that almost all were relatives; most were known one to the other, and trusted; a shipowner used to marry a ship-owner's daughter; private shares were held by villagers and all together (Captain and crew) owned ships and transported cargo ${ }^{65}$. This is the way by which shipping tradition has been created and extended over 5 generations so far. Tradition found as a representative factor to only half (49\%) of the tonnage owned by the top ( $\geq 1 \mathrm{~m} \mathrm{dwt}$ ) 74 companies we have examined in 2016.

Greeks-mainly through their shipping investment policy-maintained their top position by pursuing economies of scale in new-buildings and capital cost control by building larger sister ships in a series. Greeks also knew best $2^{\text {nd }}$ hand ship markets: they bought 285 used ships at "rock bottom" prices in 2016, larger and younger, by paying $\$ 1,320,000$ additional money on average or a total of $\$ 376 \mathrm{~m}$ extra. They also sold their older and smaller ships at a lower price. So, their fleet did not diminish much, but remained intact or even increased.

In the entire history of Greek-owned shipping-in the past and more frequently after 1945-a set off movement noticed. For Greeks to disagree one with the other is something to expect. It seems that set off provided to certain family-members the freedom they deprived from, and the wings they lacked of, and by adding their animal spirits, they flew high in the sky... Set off companiesmore important for us-progressed faster than the companies they came from and made Greek-owned fleet indeed greater. In 201614 set off shipping companies contributed $\sim 110 \mathrm{~m}$ dwt to top companies ( $\geq 1 \mathrm{~m} \mathrm{dwt}$ ).

\section{References}

[1] Sturmey, S.G. (1962) British Shipping and World Competition. New Edition 2010, The Athlone Press, University of London.

[2] Stopford, S. (2009) Maritime Economics. 3rd Edition, Routledge, London. https://doi.org/10.4324/9780203891742

[3] Deakin, B.M. and Seward, T. (1969) Productivity in Transport: A Study of Employment, Capital, Output and Technical Changes. Cambridge University Press.

\footnotetext{
${ }^{65}$ High profits-in gold—gained by Greek owners during Napoleonic Wars, 1799-1815.
} 
[4] Lawrence, S.A. (1972) International Sea Transport: The Years Ahead.

[5] Svendsen, A.S. (no date) The Internationalization of Shipping Enterprises. ISR Bergen.

[6] Metaxas, B.N. and Parker, W.N. (1980) Towards Estimated the Values of Ships over Time, Maritime Policy \& Management.

[7] Farthing, B. and Brownrigg, M. (1997) Farthing on International Shipping. 3rd Edition, LLP.

[8] Goulielmos, A.M. (2017) The "Kondratieff Cycles" in Shipping Economy since 1741 and till 2016. Modern Economics, 8, 308-332. https://doi.org/10.4236/me.2017.82022

[9] Haralambides, H. (2017) Globalization, Public Sector Reform, and the Role of Ports in International Supply Chains. Maritime Economics \& Logistics, 19, 1-51. https://doi.org/10.1057/s41278-017-0068-6

[10] Chrzanowski, I.H. (1974) Concentration and Centralization of Capital in Shipping. Saxon House Studies.

[11] Sletmo, G.K. and Holste, S. (1993) Shipping and the Competitive Advantage of Nations: The Role of International Ship Registers. Maritime Policy \& Management, 20, 243-255. https://doi.org/10.1080/03088839300000016

[12] Sletmo, G.K. (1989) Shipping's Fourth Wave: Ship Management and Trade Cycles. Maritime Policy \& Management, 16, 293-303. https://doi.org/10.1080/03088838900000049

[13] Perry, G. (1994) The Right Place at the Right Price-Locations for Ship Management. International Ship Management, 4, 43-48.

[14] Chapman, S.E. (1994) Ship Management under Pressure. International Ship Management, 4, 7-12.

[15] Goulielmos, A.M., Giziakis, C.V. and Palari, V. (2011) Advantages and Disadvantages of Managing Own Ships by a Third Party Ship Management Company: An Empirical Investigation. Shipping \& Transport Logistics, 3, 126-150. https://doi.org/10.1504/IJSTL.2011.039375

[16] Metaxas, B.N. (1985) The Economics of the Flags of Convenience. Papazisis Editions, Athens. (In Greek)

[17] Goulielmos, A.M. (2006) Management of Shipping Companies. Vol. B, 3rd Edition, Stamoulis Editions, Athens. (In Greek)

[18] Harlaftis, G. (1996) A History of Greek-Owned Shipping: The Making of an International Tramp Fleet, 1830 to the Present Day. Routledge, London.

[19] Theotokas, J. and Harlaftis, G. (2007) Greek Shipowners and Shipping Enterprises: Organization, Management and Strategy. Alexandria Editions, Athens, Leadership in World Shipping (2009) from Palgrave. (In Greek)

[20] Besanko, D., Dranove, D., Shanley, M. and Schaefer, S. (2013) Economics of Strategy. 6th Edition, International Student Version, John Wiley \& Sons, Singapore.

[21] Whittaker, G. (2016). A Nation with the Sea in Its Soul, TW+/ http://www.tradewindsnews.com/

[22] Goulielmos, A.M., et al. (2013) Oil Transport Management. Springer, London, pp. 27-59.

[23] Whittaker, G. (2016) Angelicoussis' Ancestors...They Were No Angels, Island Stories, $\mathrm{TW}+/$ http://www.tradewindsnews.com/ 


\section{Appendix}

Table A1. The main characteristics of the 74 top owning ( $\geq 1 \mathrm{~m} \mathrm{dwt}$ ) Greek ship-owning families \& companies (end 2016)

\begin{tabular}{|c|c|c|c|c|c|c|}
\hline Company's name/position in dwt/owner's name & $\begin{array}{l}\mathrm{DWT}(\mathrm{m}) \\
\text { round. }\end{array}$ & $\begin{array}{l}\text { No. of } \\
\text { ships }\end{array}$ & Traditions & Generations & Origin & Set off \\
\hline $\begin{array}{l}\text { “Aeolos"/"Andros"/"IME"-pos. } 25^{\text {th }} \text {-Epam. } \\
\text { Embiricos }^{66}\end{array}$ & 3.72 & 27 & $\mathrm{~T}$ & 4 & Andros & 1969 \\
\hline $\begin{array}{l}\text { “Alcyon Sh. Co. Ltd"-pos. } 72^{\text {nd }}-\text { Dampasis }^{67} \text { Bros } \\
\text { (1840s; George D) }\end{array}$ & 1.13 & 7 & $\mathrm{~T}$ & 3 & Andros & - \\
\hline $\begin{array}{l}\text { “Almi” tankers-“Fairsky"-pos. } 42^{\text {nd }}-K \text { Fostiropou- } \\
\operatorname{los}^{68}(1960-)-A l k y o n ?\end{array}$ & 2.26 & 13 & - & 1 & Pella & - \\
\hline "Altomare SA"-pos. $65^{\text {th }}$-Giannopoulos Fotis & 1.30 & 10 & - & 1 & Pelop.? & - \\
\hline $\begin{array}{l}\text { "Anangel-Maran tankers/Gas"-Angelicoussis J-pos. } \\
1^{\text {st } 69} \text {-Maria: his daughter joined in } 2008\end{array}$ & 22.30 & 115 & $\mathrm{~T}$ & 3 & Pelop./Chios & $\begin{array}{l}1968 ; 1971 ; \\
2000 \text { Anna } \\
\text { from John }\end{array}$ \\
\hline "Andriaki" (1953)-pos. 46 ${ }^{\text {th }}$-Goulandris N J0 & 2.02 & 15 & $\mathrm{~T}$ & 4 & Andros & $\begin{array}{l}1939 ; 1946- \\
7 ; 1952\end{array}$ \\
\hline $\begin{array}{l}\text { Angelicoussis Anna (plus her husband: Chr. } \\
\text { Kanellakis-“Alpha Tankers")-pos. } 8^{\text {th }} \text {-(1950) “Ame- } \\
\text { thyst” Co-“Pantheon” Co }\end{array}$ & 8.10 & 48 & $\mathrm{~T}$ & 2 & Pelop./Chios & $\begin{array}{l}2000 \text { from } \\
\text { John }\end{array}$ \\
\hline $\begin{array}{l}\text { Angelopoulos C-pos. 34 }{ }^{\text {th }} \text {-(1961)-(“Arcadia Co")- } \\
\text { "Aegean bulk Co" }\end{array}$ & 3.12 & 30 & - & 4 & Pelop./Arkadia & 1998 \\
\hline $\begin{array}{l}\text { "Athenian Sea Carriers"71 }- \text { pos. } 49^{\text {th }} \text {-Minos X. } \\
\text { Kyriakou-1917 }\end{array}$ & 1.91 & 6 & $\mathrm{~T}$ & 3 & Constant-inople & - \\
\hline $\begin{array}{l}\text { "Atlantic Bulk Carriers Ltd" (1995)-pos. 70 }{ }^{\text {th }} \text {-John \& } \\
\text { George Kumantaros }{ }^{72}\end{array}$ & 1.14 & 19 & $\mathrm{~T}$ & 4 & Pelop. (Sparta) & - \\
\hline $\begin{array}{l}\text { “Atlas maritime Ltd'-pos. } 69^{\text {th }} \text {-founded } 2004 \text { by Leon } \\
\text { Patitsas-origin: Christos M Lemos (1905) }\end{array}$ & 1.15 & 8 & $\mathrm{~T}$ & 4 & Oinousses & $\begin{array}{l}1972 ; 1996 . \\
1951 ; 1959\end{array}$ \\
\hline $\begin{array}{l}\text { "Byzantine Maritime" } 1970-\text { pos. } 52^{\text {nd }}-M \\
\text { Stafylopatis }{ }^{73}-(1930)\end{array}$ & 1.67 & 28 & $\mathrm{~T}$ & 2 & Sifnos/Constantinople & - \\
\hline 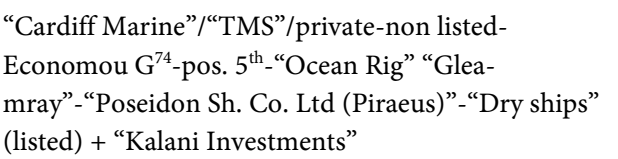 & 12.99 & 109 & - & 1 & Chios/Athens & - \\
\hline
\end{tabular}

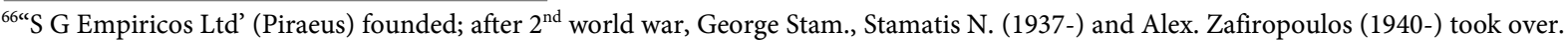

${ }^{67}$ Leader: George, a steam shipowner (1905). John had 4 sons: George, Andreas, Nicolaos and Dimosthenis.

${ }^{68}$ In 1930s he dealt with Car Sales of Mercedes-Benz. In 1956 established a car manufacturing the "Viamax". He had 3 sons: Michalis, Alex. \& John.

${ }^{69}$ From Peloponnese, but family mentions Chios. Antonis established companies in partnership: the "A. Angelicoussis \& D. Efthymiou" with Kaloudis P; the "Pegasus Ocean Services (Lon.)", (1960), with Peratikos, Xylas, Andrianopulos \& Inglessis. He established "Anangel" American Shipholding Ltd (1987), with Amex ( $1^{\text {st }}$ listed in NASDAQ and Luxemburg S E). John—his son—trained as Captain; worked with his father for 15 years and learned shipping business in site [23].

${ }^{70}$ John had 5 sons: Petros; Michalis; Basil (1886-1976); Nikolaos (1891-1957) and Leonidas (1902-1952), who established "Goulandris Bros" (1920-1952). Leonidas (in 1939-1952) took over family's passenger ships going to NY, establishing "Greek Line"; company ceased in 1975. John (1927-), his son, took over establishing "General Steam Nav." (Piraeus); he dealt also with cruising. This company was not in top 200 in 2016.

${ }^{71}$ Family company: Minoas (1917); $2^{\text {nd }}$ generation: Xenophon. $3^{\text {rd }}$ : Minos, who established “Athenian tankers Management S A" (1965). Minos passed away in summer 2017.

${ }^{72}$ John (1894-1981) founded a company in 1932-son of Stavros-together with St. Niarchos. His wife Flora from Petros Nomikos' family. $4^{\text {th }}$ generation: J G Kumantaros (1961-).

${ }^{73} 1^{\text {st }}$ Themistoclis (1888-1967); the family came to Piraeus (1930), owning 2 steamers. Present Company established (1970) by Marios (1949-). His brother: Frangiskos (1945-).

${ }^{74} \mathrm{He}$ married Evgenia, daughter of N G Livanos (1891-1968). He founded "Economou \& Co Ltd (Lon.)" (1965) and "Poseidon Sh. Co. Ltd (Piraeus)" (end 1960s). His companies: "Gleamray Mar. Inc." owned 1.20m and "Poseidon" 253,470 dwt (2016). 


\section{Continued}

\begin{tabular}{|c|c|c|c|c|c|c|}
\hline $\begin{array}{l}\text { "Carras J5 (Hellas SA)"-pos. } 73^{\text {rd }} \text {-est. by John J. } \\
\text { Carras (1852-1927)-John Michalis Carras }\end{array}$ & 1.07 & 9 & $\mathrm{~T}$ & 3 & Chios & - \\
\hline $\begin{array}{l}\text { "Centrofin"/“Marine Trust”-pos. 22 }{ }^{\text {nd }} \text {-Dimitris } \\
\text { Prokopiou (children: John; Helen) }\end{array}$ & 3.94 & 27 & - & 2 & Athens? & 1996 \\
\hline "Chandris (Hellas) Inc." ${ }^{76}$-pos. $21^{\text {st }}$-(since 1938) & 3.97 & 30 & $\mathrm{~T}$ & 3 & Chios & - \\
\hline $\begin{array}{l}\text { "Consolidated Marine"-pos. } 59^{\text {th }} \text {-J S } \\
\text { Latsis }^{77} \text {-(children: John, Spyros, Marianna \& } \\
\text { Margaret)-Captain-shipowner (1945) }\end{array}$ & 1.50 & 23 & - & 2 & Pelop. (K(C)atak-olo) & - \\
\hline $\begin{array}{l}\text { "Costamare"-Constantakopoulos Vas }{ }^{78} \text {-pos. } 19^{\text {th }} \text {-est. } \\
1974-3 \text { sons-Kostis is in charge-listed }\end{array}$ & 4.90 & 65 & - & 2 & Pelop.? & - \\
\hline $\mathrm{C}(\mathrm{K})$ oustas/“Danaos”-pos. $20^{\text {th }}$-listed & 4.20 & 59 & - & 2 & Fokida & 1970 \\
\hline $\begin{array}{l}\text { "Cyprus Maritime"/“Hellenic tankers"/ } \\
\text { "Sea lines"-pos. } 29^{\text {th }} \text {-Hadjiyiannis Andr. }\end{array}$ & 3.36 & 37 & - & 1 & Cyprus & - \\
\hline $\begin{array}{l}\text { "Diamantidis"-pos. } 12^{\text {th }}-\text { "Marmaras } \\
\text { Nav."-Diamantis D-"Delta tankers" }\end{array}$ & 7.31 & 52 & - & 1 & Pontos & - \\
\hline "Diana ${ }^{79 "} /$ Containers-Palios Simos-pos. $13^{\text {th }}$-listed & 6.42 & 60 & $\mathrm{~T}$ & 4 & Chios & - \\
\hline $\begin{array}{l}\text { "Dorian }{ }^{80 " ~ H e l l a s ' / “ L P G ”-p o s . ~} 60^{\text {st }} \text {-John } \\
\text { Hadjipateras }\end{array}$ & 1.42 & 24 & $\mathrm{~T}$ & 4 & Oinousses & - \\
\hline $\begin{array}{l}\text { “Dynacom”/ "Dynagas”/“Sea Traders”-Procopiou G } \\
\text {-pos. } 4^{\text {th }}\end{array}$ & 13.18 & 104 & - & 1 & Athens? & 1996 \\
\hline "Eletson ${ }^{81}$ corp."-pos. $50^{\text {th }}-1966$ & 1.77 & 33 & - & 2 & Piraeus? & - \\
\hline $\begin{array}{l}\text { "Empire navigation"-“Alma"-pos. } 32^{\text {th }} \text {-Stamatis } \\
\text { Molaris }^{82}\end{array}$ & 3.23 & 40 & - & 1 & $?$ & - \\
\hline 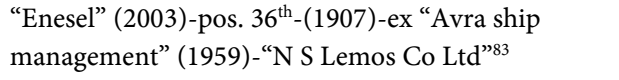 & 2.89 & 18 & $\mathrm{~T}$ & 5 & Oinousses & 1983 \\
\hline $\begin{array}{l}\text { "Enterprises shipping \& trading"-“Golden energy" } \\
\text {-pos. } 33^{\text {rd }} \text {-Victor Restis }\end{array}$ & 3.22 & 37 & - & 1 & $?$ & - \\
\hline $\begin{array}{l}\text { "Eurobulk"84/"Euroseas"-pos. 63 } 3^{\text {rd }-P i t t a s} \\
\text { fam.-"Chios Navigation (Hellas) Ltd" }=811,662 \mathrm{dwt}\end{array}$ & 1.35 & 30 & $\mathrm{~T}$ & 3 & Chios & - \\
\hline
\end{tabular}

${ }^{75}$ John Mich. Carras (1915-) established “Carras Ltd” (1938) with his father. He married a niece of S Livanos and established "Carras (Hellas) Ltd (Piraeus)".

${ }^{76}$ Family leader: John (1890-1942), a shipowner. His sons: Dimitris (1921-1980); Antonis (1924-1984). Dimitris's sons: John and Michalis, from his marriage to Myrto Pnevmaticos-took over in 1942. They established "Chandris Lines", with USA and Australian destinations and Chandris-Fantasy Cruises (1980s-) \& Celebrity Cruises (1990s-1997).

${ }^{77}$ Leader: John (1910-2003); he established a refinery in end-1960s and the "Bilinder marine" company (1990s).

${ }^{78}$ Family leader: Vassilis, who established the company in 1974.

${ }^{79}$ Leader: Captain Pant. Palios (1911-1966), shipowner of sail ships and steamers, having 4 sons (Antonis, Simos, Markos \& John). In 1965, Pantelis_and his son Simos-with partners: El. Veniamis and Isid. Sarantis, re-appeared in ship-owning (Pantelis passed away). By 1969 Simos had 3 ships and in 1972 founded "Diana Sh. Agencies" with members of his family.

${ }^{80} 4^{\text {th }}$ generation - the grandsons of J K-worked in family's companies since 1970s. John (1950-), who married Koumantaros' daughter, in cooperation with his uncle N M Lyras, founded "Dorian" (Hellas) (1975).

${ }^{81}$ Company established by 3 families, with kinship ties, and 4 ex-Captains: Karastamatis, Kertsikoff and Hadjieleftheriadis (2).

${ }^{82}$ He used to be CEO of "Quintana Mar. Ltd" (2005-2008), which merged with "Excel”. He founded "Alma Mar". in 2008 and "Product Sh. Ltd". He was the lead architect of "Empire Nav." He is involved in "Empire Bulkers" too.

${ }^{83}$ Captain Antonis (1854-1927) was son of George (1810-1897), a steam-shipowner (1907), who married Katigko D. Pateras. He had 4 sons, all Captains: Dimitris (1884-1956); Pantelis (1893-1957)—an engineer too; Spyros (1897-1962) and Polydoros (1902-1972), who established ${ }^{83}$ (1937) "Lemos \& Pateras Ltd (Lon.)" (ceased in 1986). C P Laimos (1917-1985) established "P L P Sh. Co SA" (1990) with Panagos K Laimos, C M Los and A Pythis and "Acomarit-PLP (Hellas) Ltd" (1995). Not in top 200 companies in 2016.

${ }^{84}$ Family owned sail and steam ships (1907) for over 100 years. Nikolaos F Pittas (1837-1913) had 5 sons: George (1869-1957); John (1871-1945); Frangoulis (1873-1956); Dimitris (1880-1972) and Aristidis (1888-1967). Nikolaos and his sons (1900s) established "Nikolaos F Pittas and Sons", which after father's death renamed "Brothers G N Pittas \& Partners". "Chios Nav. Co Ltd" established (1960) by brothers Nikolaos and John Ar. and brothers Isidoros and Dimitris Karoussis. "Nefeli Sh. Co" (Piraeus) established (early 1960s) run by Nikos G. The "Chios Nav. (Hellas) Ltd" established (early 1970s). Aristidis and Nikos plus Aristidis P in cooperation with Petros Pappas were involved in "Oceanbulk Mar. S A' (1991). “Eurobulk Ltd” established (1995) by John' brothers: Aristidis, Nikos and Manolis. 


\section{Continued}

\begin{tabular}{|c|c|c|c|c|c|c|}
\hline $\begin{array}{l}\text { "Eurotankers Inc."-pos. } 62^{\text {nd }} \text {-since } 1990 \text {-Ilias and } \\
\text { Michalis Gotsis }\end{array}$ & 1.35 & 13 & - & 1 & $?$ & - \\
\hline $\begin{array}{l}\text { "Euronav Hellas”-“Gaslog LNG”-pos. } 2^{\text {nd }}-P \\
\text { Livanos }\end{array}$ & 16.80 & 95 & $\mathrm{~T}$ & 3 & Chios & - \\
\hline $\begin{array}{l}\text { "European Product Carriers"/“Navigation"-pos. } \\
64^{\text {th }} \text {-Karnessis Fam. }\end{array}$ & 1.32 & 22 & - & 1 & $?$ & - \\
\hline Frangou Ang./“Navios"-pos. $3^{\text {rd }}$ & 14.55 & 142 & $\mathrm{~T}$ & 5 & Chios & 2001 \\
\hline $\begin{array}{l}\text { "Gener8 Maritime"-1997-listed NYSE-P C } \\
\text { Georgiopoulos-pos. } 6^{\text {th }}\end{array}$ & 9.38 & 40 & - & 1 & Pelop. & - \\
\hline $\begin{array}{l}\text { "Gleamray Maritime"-pos. } 67^{\text {th }} \text {-A G Economou } \\
\text { company }\end{array}$ & 1.20 & 14 & - & 1 & Chios & - \\
\hline "Goldenport"/“Oceangold"-pos. $48^{\text {th }}$-Paris Dragnis & 1.92 & 39 & - & 1 & $?$ & - \\
\hline "Hellespont"-pos. $56^{\text {th }}$-Papachristidis Phr. ${ }^{85}(1946)$ & 1.61 & 24 & - & 3 & Kavalla & - \\
\hline $\begin{array}{l}\text { Igglessis fam. }{ }^{86}-\text { pos. } 40^{\text {th }}-(1900)-“ S a m o s \\
\text { steamship co" }\end{array}$ & 2.50 & 24 & $\mathrm{~T}$ & 4 & Samos & $\begin{array}{l}1963 ; \\
1991\end{array}$ \\
\hline "Iolcos Hellenic Marine"-pos. 61 ${ }^{\text {st }}$-Themis Petrakis & 1.39 & 17 & - & 1 & $?$ & - \\
\hline $\begin{array}{l}\text { Kollakis }{ }^{87} \text { L/“Chartworld”/“Charterwell”-pos. } \\
35^{\text {th }}-(1900)\end{array}$ & 2.94 & 64 & $\mathrm{~T}$ & 3 & Oinousses & 1974 \\
\hline $\begin{array}{l}\text { "Kyklades Maritime Corp." (end 1980s)-Alafouzos } \\
\text { family }{ }^{88} \text {-pos. } 55^{\text {th }} \text {-Themistoklis (son)-John (son) est. } \\
\text { "Ermis Mar. Corp." early 1990s }\end{array}$ & 1.65 & 13 & $\mathrm{~T}$ & 2 & Santorini & - \\
\hline $\begin{array}{l}\text { Laskaridis }{ }^{89} / \text { “Alison”/“Unimed”-“Baltmed”-pos. } 24^{\text {th }} \\
\text {-son: Odysseus }\end{array}$ & 3.77 & 72 & - & 1 & Crete? & - \\
\hline $\begin{array}{l}\text { Lemos Michalis/“Nereus sh. SA"-pos. } 54^{\text {th }}-\mathrm{C} \text { M } \\
\text { Lemos }^{90}\end{array}$ & 1.66 & 11 & $\mathrm{~T}$ & 5 & Oinousses & - \\
\hline 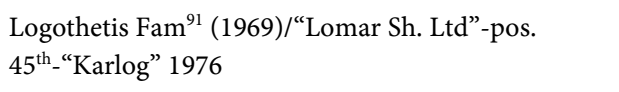 & 2.04 & 65 & $\mathrm{~T}$ & 2 & Andros & - \\
\hline $\begin{array}{l}\text { Marinakis/“Capital ship management"-"Product } \\
\text { Carriers" (listed)-pos. } 16^{\text {th }} \text {-Crude carriers (listed) }\end{array}$ & 5.75 & 60 & - & 1 & Crete? & - \\
\hline
\end{tabular}

${ }^{85}$ Family led by Phrixos (1901-1981); moved to Montreal (1930s). Dominated in Great Lakes (1960-1965). The $2^{\text {nd }}$ generation took over (1965) (Basil, 1944-), a PhD, trained in site, and "honoris cause Doctor of Science" from City University (2013). Phrixos (1981-) joined the company in 2007 and in 2009 was CEO (see Laursen W, 2016: For 70 years the family-owned company has survived-and prospered-by adapting to changing times, internet).

${ }^{86}$ Dimitris had 5 sons: Stamatis, John, Nikolaos, Socratis and Hercules; he bought a steamship (1900). They established "D Igglesis and Sons". 3rd generation: 7 sons: from Stamatis 2, (Nikolaos \& Ippocratis ${ }^{\star}$ ), from Nikolaos 3, (Manolis, Dimitris ${ }^{\star}$ and George ${ }^{\star}$ ), from Socratis 1, (Dimitris ${ }^{\star}$ ) and from Hercules 1, (Fokion). They established "Pegasus Ocean Serv. Ltd" (1963) with Peraticos, Andrianopoulos, Aggelicoussis, Efthymiou and Giannaga families (till 1985). $\left(^{*}\right)$ these were in the management of "Pegasus'.

${ }^{87}$ Michael owned sail ships (1900). Stefanos (1911-1994) and Pantelis (1906-1965 or 1966), were ex-captains. Stefanos in 1946-7 owned a small number of dry cargoes, and also signed on as a Captain. He established-with a partner- "the Kollakis Bros Co" (1947-1964); also established "Charterwell". In end 1980 Pantelis took over, and George (son of Stefanos).

${ }^{88}$ Aristidis passed away in May, 2017-a shipowner since 1965, est. "Glafki" (early 1970s) and "Kyklades" with his son Themistoclis (end-1980s). His son John est. (early 1990s) "Ermis".

${ }^{89}$ Konstantinos appeared (early 1950s) in shipping. The $2^{\text {nd }}$ generation joined (1975) (Thanassis and Panos).

${ }^{90}$ The patriarch was K M Laimos (1855-1930), steamships owner with partners (1909), who had 3 sons (Michalis, 1881-1941, a captain and shipowner); Panayiotis and George, a dry cargo shipowner, who used "Poseidon Sh. Agencies". C M Lemos-a Captain—(1910-1995)—was the most famous; son of Michalis. He established, with his cousins Markos and C Lyras, the "Lyras \& Lemos" (1937). He married Melpo G K Pateras and obtained Chrysanthi, Irini and Michail, who took over, and established "Nereus". Costas was a shipping entrepreneur recognized also as "Greek Croesus", who left an inheritance of $£ 20 \mathrm{~b} \ldots$

${ }^{91}$ Leader: Epaminondas (1933-), a shipowner since 1969, est. "Panard' and "Karlog” (1976) in partnership. D Karlos set off (mid-1980s). 


\section{Continued}

\begin{tabular}{|c|c|c|c|c|c|c|}
\hline $\begin{array}{l}\text { "Marine Management Services" (1991)/Bulk-pos. } \\
43^{\text {rd }} \text {-Callimanopoulos }{ }^{92} \text { Gr.-ex "Trade and Trans- } \\
\text { port" (1960)-end 1980s dealt with offshore ships }\end{array}$ & 2.16 & 20 & $\mathrm{~T}$ & 2 & Pelop./ Achaia & - \\
\hline Martinos Andr./“Minerva”-pos. $11^{\text {th }}$-son Nicholas & 7.32 & 63 & - & 1 & Pelop./Stemnitsa & 1997 \\
\hline Martinos Ath./“Eastern Med.”-pos. 15 $5^{\text {th }}$ & 6.00 & 65 & - & 1 & Pelop./Stemnitsa & 1991 \\
\hline $\begin{array}{l}\text { Martinos C/“Thenamaris”-pos. } 10^{\text {th }} \text {-est. } \\
\text { 1971-John (son set off 2000s?) }\end{array}$ & 7.42 & 74 & - & 2 & Pelop./Stemnitsa & - \\
\hline Moundreas N G93 -pos. 30 $0^{\text {th }-" N G M ~ E n e r g y "-~}$ & 3.28 & 29 & $\mathrm{~T}$ & 3 & Pelop./Mani & - \\
\hline "Navarone S A"-pos. 71 $1^{\text {st }}$-Michalis Giokas & 1.14 & 34 & - & 1 & $?$ & - \\
\hline "Neda" (1970)-pos. 23 $3^{\text {rd }}$-Lykiardopoulos ${ }^{94}$ family & 3.80 & 23 & $\mathrm{~T}$ & 4 & Cephalonia & - \\
\hline "New Shipping" Ltd/Polemis Ad.-pos. $14^{\text {th }}$ & 6.13 & 35 & $\mathrm{~T}$ & 3 & Andros & 2015 \\
\hline $\begin{array}{l}\text { Nomikos Markos }{ }^{95} \text { "Nomikos A.M. Transworld" } \\
\text {-pos. } 39^{\text {th }}\end{array}$ & 2.53 & 42 & $\mathrm{~T}$ & 4 & Santorini & - \\
\hline $\begin{array}{l}\text { Onassis }{ }^{96} \text {-Smyrna-pos. } 17^{\text {th }} \text {-nontraditional-est. } \\
\text { 1932-“Springfield Sh. Co" }\end{array}$ & 5.27 & 27 & - & 3 & Smyrna & - \\
\hline $\begin{array}{l}\text { "Optimum Ships"/“Marine”-pos. } 31^{\text {st }} \text {-Owned by } \\
\text { Scorpio Group-2014-a ship management company- } \\
\text { G Vassilakis }\end{array}$ & 3.24 & 45 & - & 1 & Crete? & - \\
\hline $\begin{array}{l}\text { Papadimitriou D N }{ }^{97} \text { "Dioryx"/“Liquimar"-pos. } 66^{\text {th }} \text { - } \\
(1850)\end{array}$ & 1.20 & 14 & $\mathrm{~T}$ & 4 & Kassos/Egypt & - \\
\hline "Phoenix Energy nav. SA"-pos. $74^{\text {th }}$-N Xylas & 1.06 & 8 & $\mathrm{~T}$ & 3 & Chios & - \\
\hline "Polemis Spyros"98 ("Polembros")-pos. $26^{\text {th }}$ & 3.59 & 21 & $\mathrm{~T}$ & 3 & Andros & $\begin{array}{l}\text { early 1970s; } \\
2015\end{array}$ \\
\hline “Polyar shi. Co. Ltd"-pos. $68^{\text {th }}$-Polys Hadjioannou & 1.17 & 20 & - & 2 & Cyprus & - \\
\hline $\begin{array}{l}\text { "Prime Mar. Group" (1999)-pos. } 44^{\text {th }}-\text { Topouzoglou } \\
\text { Sta./Chalkias/Pouleris }\end{array}$ & 2.11 & 31 & - & 1 & & - \\
\hline "Quintana Ship management" (2005)-pos. 51 & 1.76 & 14 & - & 1 & & - \\
\hline $\begin{array}{l}\text { "Safe bulkers"-“Safety"-pos. } 28^{\text {th }} \text {-Polys Hadjioan- } \\
\text { nou'99-Nikos-1959 “Troodos"-1965 “Alassia"-1995 } \\
\text { "Safety man." }\end{array}$ & 3.49 & 39 & - & 3 & Cyrpus & 1965 \\
\hline $\begin{array}{l}\text { "Sea World management”/“Sea Globe”-pos. } \\
57^{\text {th }} \text {-Laliotis Group }\end{array}$ & 1.54 & 24 & - & 1 & & - \\
\hline
\end{tabular}

${ }^{92}$ The company, since 1930s, emerged with Periclis (1892-1979), establishing "Hellenic Lines" (1934-1984).

${ }^{93}$ G M Moundreas family (1896-1968) — agents and shipbrokers; as a shipowner emerged Nikos (1939-) establishing "Good Faith" in partnership with Nikolaos Frangos (1964); he established also-with his cousins—the "Nicholas G Moundreas Sh. SA" (1974), which obtained ships (end 1980s). In 1995 joined company Chariklia, Natalia and George-his children.

${ }^{94}$ Patriarch: Nikolaos (1866-1963) — a steamship owner (1901). He had 2 sons: Panagis (1893-1983) and Gerasimos (1895-1982). Fotis (1924-), son of Panagis, joined, as well Michalis. Neda est. (1970).

${ }^{95}$ Leader: Markos Anast. Nomikos (1892-1955), owner of sail ships. His son Anastasios (1920-1993) was a Captain; he married Aggeliki from the Vergotis family (1955) and became a shipowner (1959) and est. “A.M. Nomikos Worldwide Maritime Agencies” and “A.M. Nomikos and Sons (UK) Ltd”. His 3 children (Kalypso Stratakis, 1956-; Annika Papantoniu, 1957-and Markos, 1965-), took over after his death. $4^{\text {th }}$ generation took over too. Nomikos E. Corp. owned 311,705 dwt in 2016. This most probably belongs to Evangelos P Nomikos (1902-1985), who est. "Evangelos P. Nomikos, Commercial and Maritime Enterprises" (early 1980s).

${ }^{96}$ Born in 1903 (-1975); married to Tina S Livanos (1946) and gave birth to Alexandros (1948-1973) and Christina (1950-1988). He bought island "Scorpios" (1963). He married Jacqueline Bouvier-widow of J F Kennedy (1968).

${ }^{97}$ Founder: John, resident of Egypt (1880). His son Dimitris (1871-1945) had 9 children. The following took over in 1936: John (1907-1998), Kanakis (1910-1955), George (1916-) and Nikolaos (1922-). "Dioryx" established-(by D N Papadimitriou) (1965).

${ }^{98}$ Spyros's son Leonidas (1909-1971) in cooperation with his brothers Michalis (1906-1995) and Avgustis (1920-1985) took over the company.

${ }^{99} 1^{\text {st }}$ was Vasos (1933-2002). Polys is the elder son of Vasos, who joined company (end 1980s). Nikos-his younger son-joined (1999). $2^{\text {nd }}$ generation took over (2002). 


\section{Continued}

"Seanergy Maritime Holdings corp"-pos. $58^{\text {th }}-5$ partners (Al. Comninos/ Ilias Kulukundis)

"Star Bulk Car."/“Product ship.”/“Oceanbulk Cont."-Pappas Petros (1953-)-pos. $7^{\text {th }}$-plus “Oaktree Cap. Management"

"Sun enterprises"/“Alios" (new name 2014)-pos. $47^{\text {th }}$ "S Livanos Hellas SA"-1902-George (son of Stavros)

“Target"/“Horizon tankers"/Comninos Ant. (1946-)-pos. 53 $3^{\text {rd }}$ (Em. Comninos: founder-1939 Konst. K)

Technomar Sh. Inc.-pos. $27^{\text {th }}$-Youroukos G

Transmed sh. Ltd-pos. $37^{\text {th }}$-Har. Mylonas

Tsakos-TEN-Columbia-pos. $9^{\text {th }}$-Panag. ${ }^{100}$

and Nicos (son)

"Vafias group"-pos. 38th

Vardinoyiannis ${ }^{101}$-pos. $41^{\text {st }}$ (“Varnima” 1965)-“Avin Int. S A' (2003)

Veniamis/Gabriel-pos. 18 ${ }^{\text {th }}$-“Golden Union” (1977), "World Management"

Traditional $=146.15 \mathrm{~m}$ dwt $=49 \% ; 36$ companies;

1.50

10

$\mathrm{T}$

5

Syra/Kassos

End-1980s

8.60

92

1

Constant-inople

1.96

22

$\mathrm{T}$

Chios

21

$\mathrm{T}$

Syra

End 1980s

3.52

7.90

2.63

2.33

5.20

$298.64 \mathrm{~m}$

Dwt
59

21

81

$\mathrm{T}$

Cyprus?

Chios

Athens?

Crete

Chios

1976;

Sources: "Naftiliaki"-Summer 2016; Theotokas-Harlaftis [19]; companies' internet sites; phone interviews; data: "Marine Information Services". Three ship management companies excluded or owned by non-Greeks: V.ships; ADK and Stamco. Errors and omissions excluded.

\footnotetext{
${ }^{100} \mathrm{He}$ signed on at age of 16; graduate of the "Livanos Marine Academy"; at the age of 26 was Captain (1954-1965); he studied chartering and insurance (UK).

${ }^{101}$ The founder was Nikos (1931-1973). He founded Varnima Corp. Int. SA (1965). After his death his brothers Vardis and Theodoros took over.
} 